\title{
Synthesis of bi- and bis-1,2,3-triazoles by copper-catalyzed Huisgen cycloaddition: A family of valuable products by click chemistry
}

\author{
Zhan-Jiang Zheng ${ }^{* 1}$, Ding Wang ${ }^{1}$, Zheng $\mathrm{Xu}^{1}$ and Li-Wen $\mathrm{Xu}^{* 1,2}$
}

\section{Address:}

${ }^{1}$ Key Laboratory of Organosilicon Chemistry and Material Technology of Ministry of Education, and College of Material, Chemistry and Chemical Engineering, Hangzhou Normal University, Hangzhou 310012, P. R. China and ${ }^{2}$ State Key Laboratory for Oxo Synthesis and Selective Oxidation, Lanzhou Institute of Chemical Physics, Chinese Academy of Sciences, Lanzhou, P. R. China

\section{Email:}

Zhan-Jiang Zheng* - zzjiang78@hotmail.com; Zheng Xu -

Zhengxu@hznu.edu.cn; Li-Wen Xu* - liwenxu@hznu.edu.cn

* Corresponding author

Keywords:

bistriazoles; click chemistry; cycloaddition; homogeneous catalysis;

oxidative coupling

\author{
Beilstein J. Org. Chem. 2015, 11, 2557-2576. \\ doi:10.3762/bjoc.11.276 \\ Received: 31 August 2015 \\ Accepted: 20 November 2015 \\ Published: 11 December 2015 \\ This article is part of the Thematic Series "Copper catalysis in organic \\ synthesis". \\ Guest Editor: S. R. Chemler \\ (C) 2015 Zheng et al; licensee Beilstein-Institut. \\ License and terms: see end of document.
}

\begin{abstract}
$\mathrm{The} \mathrm{Cu}(\mathrm{I})$-catalyzed azide-alkyne cycloaddition reaction, also known as click chemistry, has become a useful tool for the facile formation of 1,2,3-triazoles. Specifically, the utility of this reaction has been demonstrated by the synthesis of structurally diverse biand bis-1,2,3-triazoles. The present review focuses on the synthesis of such bi- and bistriazoles and the importance of using copperpromoted click chemistry (CuAAC) for such transformations. In addition, the application of bitriazoles and the related CuAAAC reaction in different fields, including medicinal chemistry, coordination chemistry, biochemistry, and supramolecular chemistry, have been highlighted.
\end{abstract}

\section{Introduction}

Since its discovery by Huigsen and co-workers fifty years ago [1-4], the Huisgen cycloaddition of azides to alkynes has gained much attention due to its potential to yield a wide variety of triazoles with structurally diverse and functionalized groups, especially with respect to biological activity [5-8]. Originally, this transformation was typically carried out at high temperature and resulted in a mixture of the 1,4 and 1,5 regioisomers
(Scheme 1). Fortunately, representing a milestone in this field, the application of $\mathrm{Cu}(\mathrm{I})$ as the catalyst was reported by Sharpless and Meldal in 2002 [9,10]. In this work, the Huisgen reaction worked well under mild conditions, giving the desired triazoles with high yield, good regioselectivity, and quite high functional-group tolerances (Scheme 1). Since then, the so-called field of "click chemistry" has been extensively 


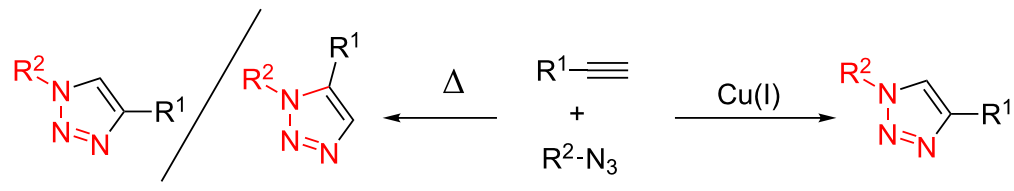

ca. $1: 1$

Scheme 1: The synthesis of triazoles through the Huisgen cycloaddition of azides to alkynes.

investigated and recognized as an epoch-making progress in organic synthesis and green chemistry [11-15].

After many years of research, it was proven that the $\mathrm{Cu}(\mathrm{I})$ catalyzed azide-alkyne cycloaddition ( $\mathrm{CuAAC}$ reaction) could be performed under various conditions according to the need of click chemistry using the catalysis of various copper salts that generate $\mathrm{Cu}(\mathrm{I})$ sources in situ [16]. As a brief summary, the copper(I)-promoted click chemistry has the following features: (1) The most preferred methods for the formation of $\mathrm{Cu}(\mathrm{I})$ involve the use of $\mathrm{CuSO}_{4}$ and a reducing agent in an aqueous solution. Most commonly, a large excess of sodium ascorbate with respect to the copper catalyst is the favored reducing agent, and a water/alcohol mixture is the favored solvent. This catalyst system combines the advantage of not requiring inert gas to prevent the $\mathrm{Cu}(\mathrm{I})$ from oxidation to $\mathrm{Cu}$ (II) during the reaction, and not requiring the tedious work-up and purification steps. (2) Other frequently used $\mathrm{Cu}(\mathrm{I})$ sources are $\mathrm{CuI}$ or $\mathrm{CuBr}$. In general, $\mathrm{CuI}$ has been used in organic solvents such as $\mathrm{CH}_{3} \mathrm{CN}$, THF or toluene, and the active $\mathrm{Cu}(\mathrm{I})$ species was further stabilized by the addition of excess base. In addition, many other $\mathrm{Cu}(\mathrm{I})$ salts are used in $\mathrm{CuAAC}$ reactions owing to improved solubility or increased rate as compared to the $\mathrm{CuSO}_{4}$ /sodium ascorbate or $\mathrm{CuI}$ catalytic system. (3) The third type of $\mathrm{Cu}(\mathrm{I})$ source is generated by the oxidation of $\mathrm{Cu}$ metal. The $\mathrm{Cu}(0)$ species (found in forms such as turnings, wire, powder or nanoparticles) in the presence or absence of $\mathrm{Cu}(\mathrm{II})$ in aqueous media also provides the key active $\mathrm{Cu}(\mathrm{I})$ in some $\mathrm{CuAAC}$ reactions.

As an important supplement to the classic Huisgen cycloaddition promoted by copper catalysis, this review will deal with the copper-catalyzed syntheses of bi- and bistriazoles or their analogues by click chemistry, such as those linked directly or by spacers. The synthetic approaches for the preparation of biand bistriazoles are discussed in detail and their application is discussed briefly in each section. Accordingly, the following three types of bi- and bistriazoles will be primarily presented: (1) The 4,4'-linked symmetric or unsymmetrical bitriazoles. (2) The 5,5'-linked symmetric bitriazoles. (3) The bistriazoles formed through spacers from the dialkyne or diazide substrates.

\section{Review}

\section{The synthesis of 4,4 '-bitriazoles}

The 4,4'-bitriazoles can be realized from a double CuAAC reaction between various sources of 1,3-butadiynes with the substituted azides. In general, two different methods have been developed for the construction of the 4,4'-bitriazoles: (1) The one-pot double CuAAC reaction of 1,3-butadiyne with azides. (2) Two successive $\mathrm{CuAAC}$ reactions with different or same azides that require the deprotection of the second reactive site to liberate another alkyne moiety.

In 2007, Monkowius et al. reported that the 4,4'-bitriazoles 3 could be synthesized by the two-fold click reaction between 1,3-butadiyne and substituted organic azides [17], and the reaction was catalyzed by a catalytic amount of $\mathrm{CuI}$ in acetonitrile in the presence of 2,4-lutidine. The desired, symmetrical 4,4'bitriazoles 3 were obtained in good yield (76-82\%, Scheme 2). However, the substrate 1,3-butadiyne (1) is difficult to handle because of its high reactivity and instability.

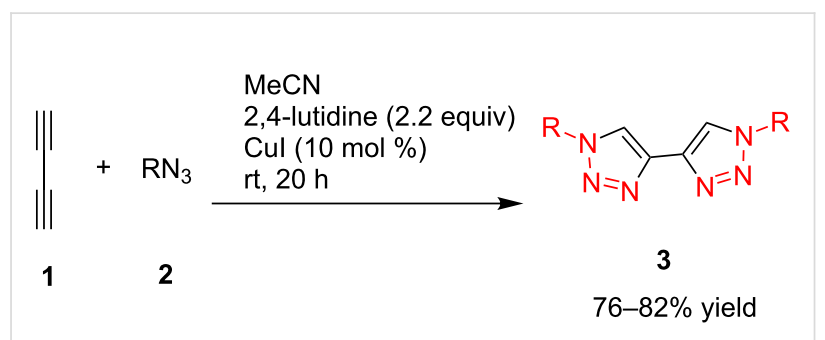

Scheme 2: The synthesis of symmetrically substituted 4,4'-bitriazoles.

Later in 2009, Fiandanese et al. proposed that unsymmetrically substituted 4,4'-bi-1,2,3-triazoles can be prepared in an easy manner [18]: starting from 1-trimethylsilyl-1,3-butadiyne (4) the 4-(silylalkynyl)-1,2,3-triazoles $\mathbf{5}$ can be obtained after reaction with substituted azides catalyzed by $\mathrm{Cu}(\mathrm{OAc})_{2} \cdot \mathrm{H}_{2} \mathrm{O}$ ( 0.2 equiv). After the in situ deprotection with TBAF, followed by the CuI-catalyzed click reaction with another azide in THF in the presence of 1.2 equiv of 1,1,4,7,7-pentamethyldiethylenetriamine, the unsymmetrically 4,4'-bitriazoles 6 are obtained in good yield (52-86\%, Scheme 3). 


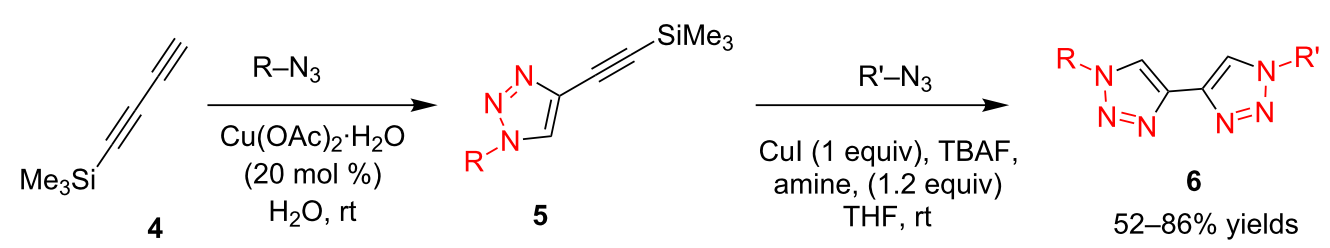

Scheme 3: The synthesis of unsymmetrically substituted 4,4'-bitriazoles.

Simpson et al. also developed this three-step procedure (CuAAC-deprotection-CuAAC) into a one-pot fashion with moderate overall yield (34-49\%) [19]. Similar to Fiandanese's strategy, Aizpurua et al. developed another synthetic method [20]: Starting with the CuAAC reaction of propargyl alcohol (7) with different azides, followed by the sequential Swern oxidation and Ohira-Bestmann homologation provided the ethynyltriazole intermediate $\mathbf{9}$, finally another $\mathrm{CuAAC}$ resulted in the formation of unsymmetrical 4,4'-bi(1,2,3-triazole)s $\mathbf{1 0}$ (Scheme 4).

\section{The synthesis of 5,5'-bitriazoles}

Originally, in the research of the CuAAC reaction, the 5,5'-bitriazoles were usually considered as an undesired side product or impurity in the Huisgen cycloaddition. In general, they are the oxidative coupling product of the triazole-copper species. The 5,5'-bitriazoles were usually formed as the major product by the facilitation of the reaction conditions or controlled by the starting substrate.

In 2007, Burgess and Angell successfully developed an oxidative coupling method for the preparation of 5,5'-bitriazole [21]. In this work, they were able to perform this reaction of azides and terminal alkynes with moderate to high yield by using a 1:1 mixture of $\mathrm{MeCN} / 2 \mathrm{M}$ aqueous $\mathrm{Na}_{2} \mathrm{CO}_{3}$ solution at $25{ }^{\circ} \mathrm{C}$ for $18 \mathrm{~h}$ in the presence of a catalytic amount of $\mathrm{CuSO}_{4}(10 \mathrm{~mol} \%)$ and one equivalent of $\mathrm{Cu}$ powder (Scheme 5). Obviously, this

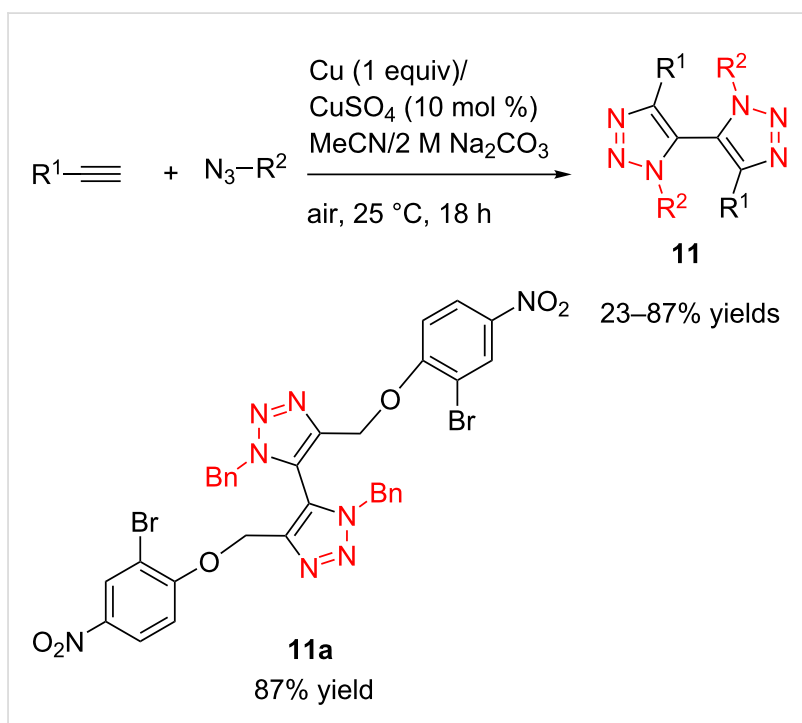

Scheme 5: The synthesis of 5,5'-bitriazoles.

method suffered from the drawback that a stoichiometric amount of $\mathrm{Cu}$ powder is required to achieve the highest activity.

In 2010, Nandurdikar et al. linked the two (or four) molecules of NO donor prodrugs together through the triazole spacers [22], which has potential application as NO-releasing materials. They first prepared the benzylidene-protected 2,2-di(azidomethyl)propane-1,3-diol containing the conformational strain.
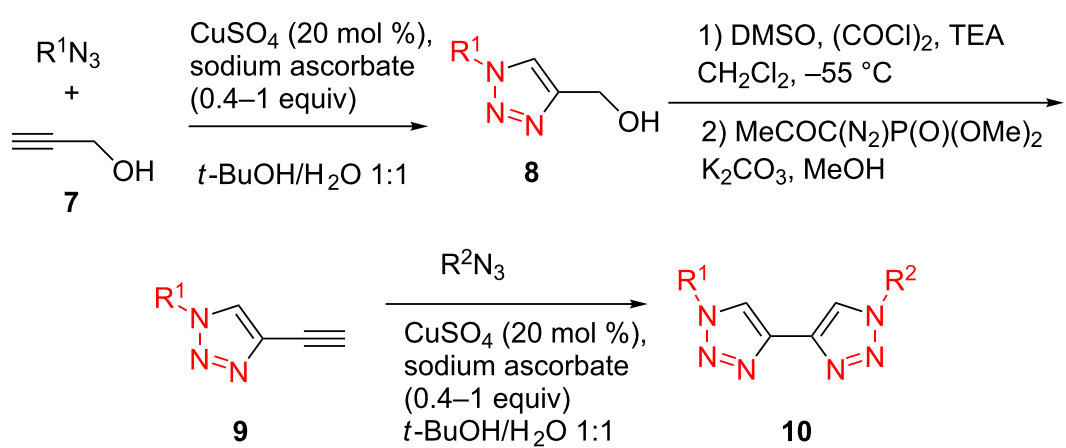
They also investigated the click reactions with various alkynes under different conditions (Scheme 6), and found that: (1) when catalyzed with $\mathrm{CuSO}_{4} / \mathrm{Na}$ ascorbate in $\mathrm{THF} / \mathrm{H}_{2} \mathrm{O}$, the reaction provided the normal bistriazoles $\mathbf{1 3}$ with moderate to good yield (60-75\%). (2) By using CuI and DIPEA in acetonitrile to perform the reaction, the sequential, CuAAC oxidative coupling gave the cyclic 5,5'-bitriazoles $\mathbf{1 4}$ as the major product (44-74\%). They demonstrated that both the reaction conditions and the conformational effect are beneficial for the formation of the 5,5'-bitriazoles.

Similarly, Urbano and co-workers performed the CuAAC reaction of 1,1'-diazidoferrocene with ethynyl [5]-helicenequinone [23], and found the open chain bistriazolylphenylhelicenequinone $\mathbf{1 7}$ could be obtained in good yield when $\mathrm{CuSO}_{4} /$ sodium ascorbate was used in THF/ $\mathrm{H}_{2} \mathrm{O}$ (Scheme 7).

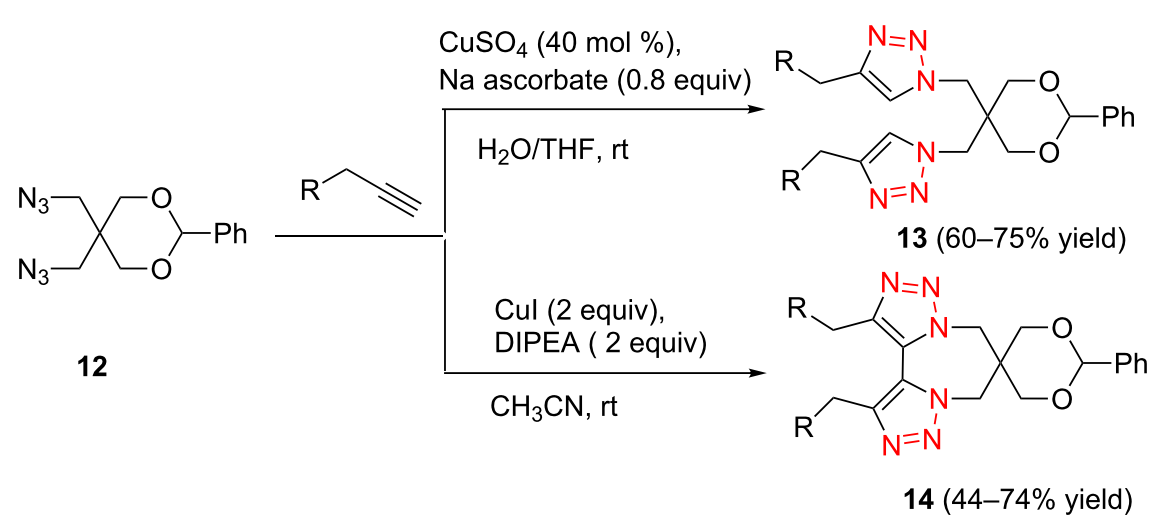

Scheme 6: The synthesis of bistriazoles and cyclic 5,5'-bitriazoles under different catalytic systems.

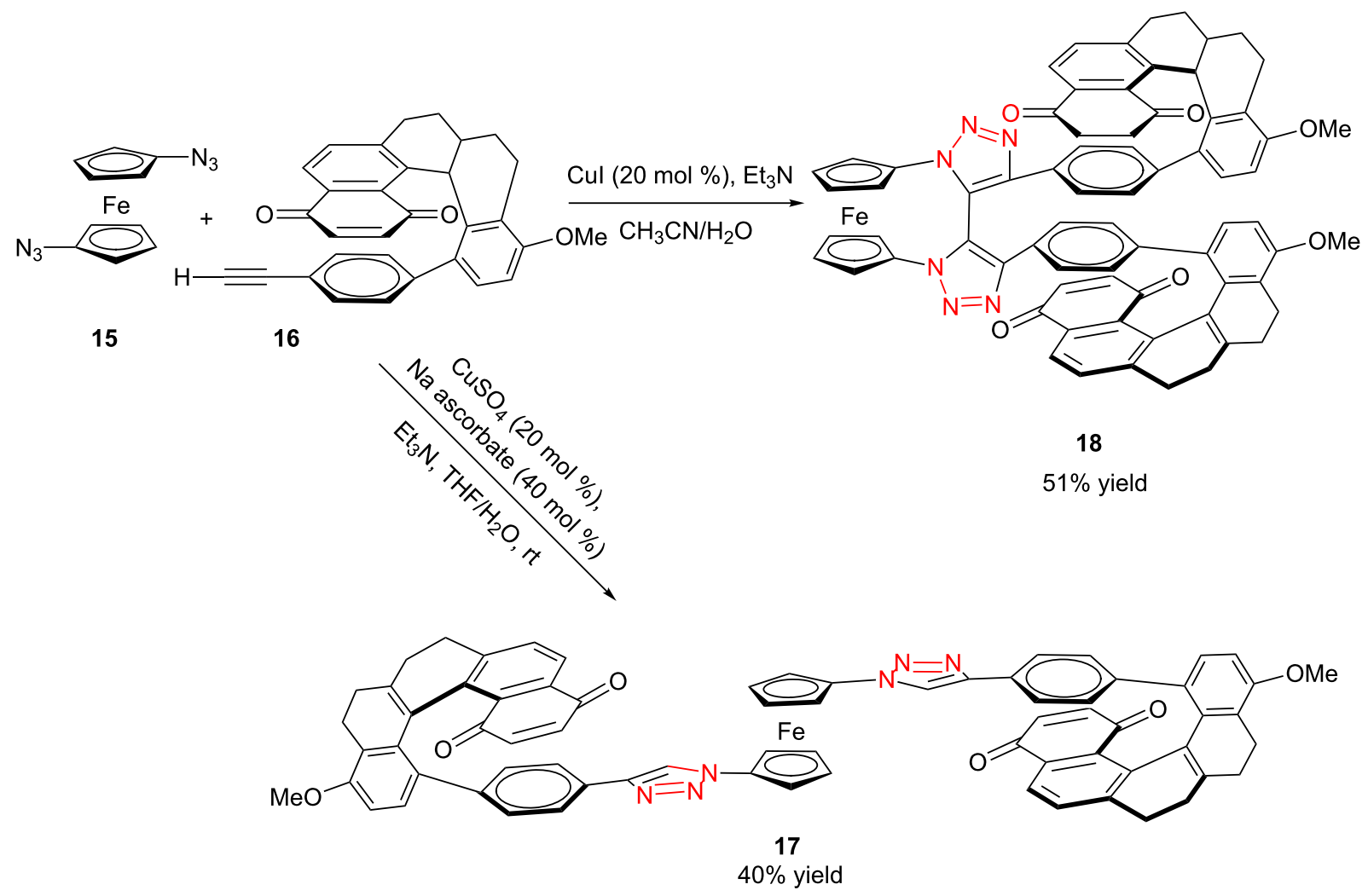

Scheme 7: The double CUAAC reaction between helicenequinone and 1,1'-diazidoferrocene. 
However, the cyclic 5,5'-bitriazole $\mathbf{1 8}$ was achieved as the major product when $\mathrm{CuI} / \mathrm{Et}_{3} \mathrm{~N}$ was used in $\mathrm{CH}_{3} \mathrm{CN}$.

In 2011, Cuevas-Yañez and co-workers demonstrated that temperature was the key factor for the formation of 5,5'-bitriazole [24]. In that work, it was found that the desired bitriazoles could be obtained in low to moderate yield when the CuAAC reaction was performed at low temperature $\left(-35^{\circ} \mathrm{C}\right)$ and high $\mathrm{NaOH}$ concentration. Subsequently, Jeon and co-workers reported a synthetic method for the construction of 5,5'-bitriazoles by using $\mathrm{CuI}$ together with 2 equiv of DIPEA [25]. The authors further demonstrated that the use of a base was also an important factor for the appropriate bitriazole yield. However, Jeon's method worked well only when the alkynes contained propargylic ethers and acetylenic amides (Scheme 8). Generally speaking, most of the above-mentioned oxidative couplingclick dimerizations merely provided the desired 5,5'-bitriazole in low yield when the alkynes or azides were linked directly with a hindered group or an aromatic moiety.

In 2012, Xu and co-workers disclosed that both the secondary and primary amine-functionalized polysiloxanes were good ligands for the copper-catalyzed Huisgen reaction of organic azides and alkynes [26]. This applied especially when the reaction was catalyzed by $\mathrm{CuCl}$ and mediated by the secondary amine-functionalized polysiloxanes at $0{ }^{\circ} \mathrm{C}$ in $\mathrm{CH}_{2} \mathrm{Cl}_{2}$, where the symmetrically $5,5^{\prime}$-coupled bitriazole was obtained as the major product (Scheme 9). All the alkynes directly linked with the aromatic moiety provided the desired bitriazoles in moderate to good yield. We believe that the key copper monotriazole intermediate formed after the first $\mathrm{CuAAC}$ reaction was stabilized by the secondary amine-functionalized polysiloxane, which further led to the formation of the bitriazole 22. The chiral D-glucopyranosyl azide and phenylacetylene reacted under $\mathrm{CuI}$ and the secondary amine-functionalized poly- siloxane catalytic system, where the desired chiral bitriazole $\mathbf{2 3}$ was obtained with good diastereoselectivity $(85: 15)$. Subsequently, the authors used this method to construct the novel, cyclic 5,5'-bitriazole 24 from binaphthol [27] (Scheme 10). Notably, this type of compound showed high selectivity over the recognition of $\mathrm{I}^{-}$, possibly due to the formation of a chargetransfer complex between the $\mathrm{I}^{-}$and the electron-deficient triazole ring.

\section{Bistriazoles formed through spacers Bistriazole synthesis with dialkyne spacers}

In the past years, bistriazoles with dialkyne spacers have gained significant attention for their potential application in supramolecular chemistry, pharmaceutical chemistry, biological chemistry and organometallic chemistry. The construction of bistriazoles from dialkynes is now well-developed, and three main methods are reported: (1) the one-pot CuAAC reactions of the terminal dialkynes with two equiv of the organic azides, providing the corresponding bistriazoles, which is the most popular method for the synthesis of bistriazoles with dialkyne spacers. (2) The second protocol is the sequential CuAAC-deprotection-CuAAC reaction for the construction of the bistriazoles. In general, the trialkylsilyl group was used as a temporary masking group for one of two alkyne moieties. Thus, this method provides the possibility of one molecule bearing two alkynes reacted with two different organic azides. (3) The third method involves the utilization of the substrate bearing two alkyne moieties with different reactivity in the successive Huisgen cycloaddition reactions: Huigsen reaction of the activated alkyne with the first azide and the CuAAC reaction of the nonactivated alkyne with another azide, leading to the corresponding bistriazoles.

In 2006, Aucagne and Leigh reported the synthesis of the TMSalkyne and terminal-alkyne bis-functionalized tripeptide [28].

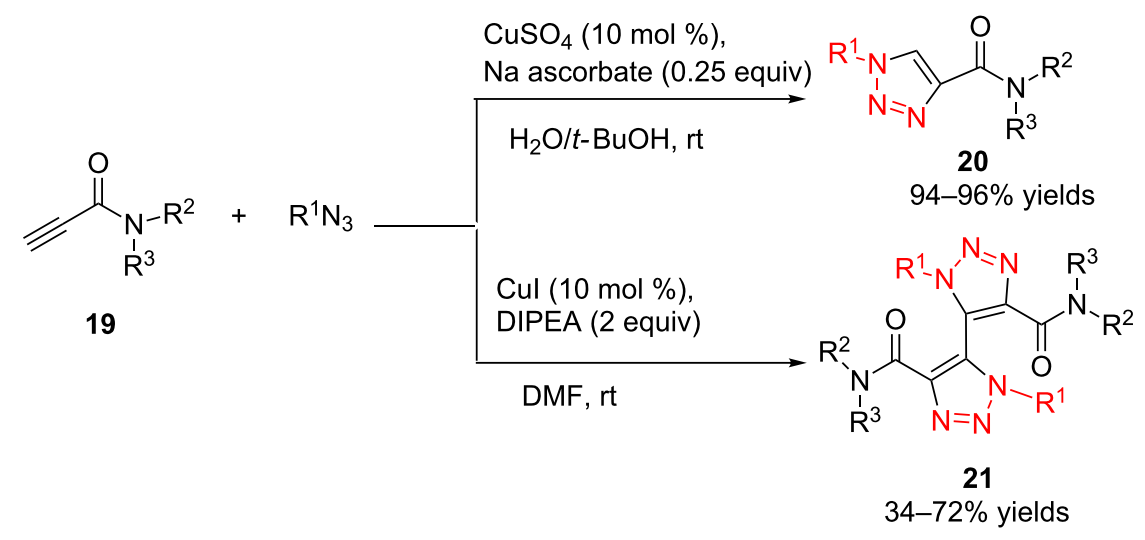

Scheme 8: The synthesis of 1,2,3-triazoles and 5,5'-bitriazoles from acetylenic amide. 

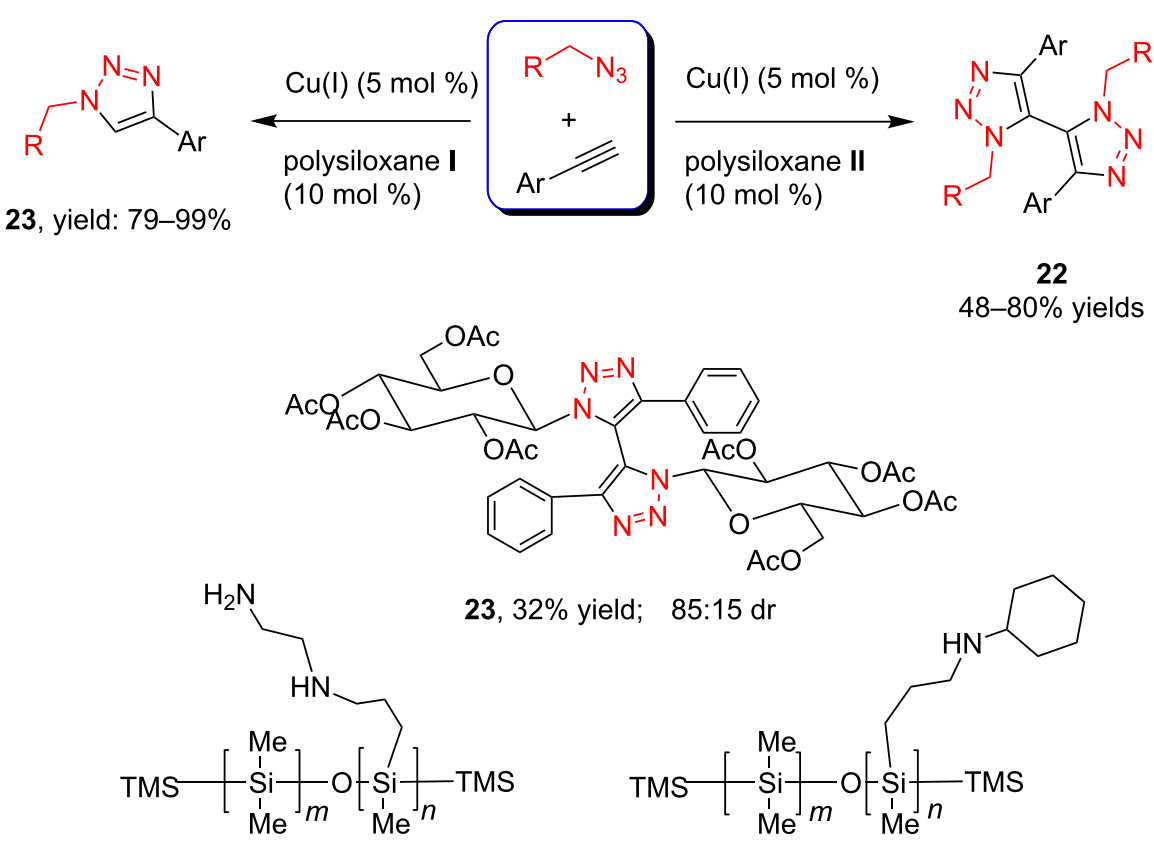

polysiloxane I: $0.21 \mathrm{mmol} \mathrm{N}$ amount/g polysiloxane II: $0.55 \mathrm{mmol} \mathrm{N}$ amount/g $M_{\mathrm{w}}=$ ca. 1900

$M_{\mathrm{w}}=$ ca. 1900

Scheme 9: The amine-functionalized polysiloxane-mediated divergent synthesis of trizaoles and bitriazoles.

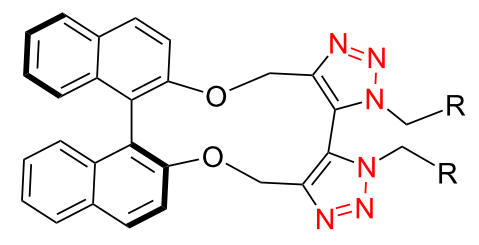

24

Scheme 10: The cyclic BINOL-based 5,5'-bitriazoles.

Here they used the CuAAC reaction of the terminal-alkynecontaining tripeptide $\mathbf{2 5}$ with the azide-containing dipeptide $\mathbf{2 6}$ in $t-\mathrm{BuOH} / \mathrm{H}_{2} \mathrm{O}$, catalyzed by $\mathrm{CuSO}_{4} /$ sodium ascorbate, providing the first triazole-bearing intermediate (Scheme 11). They then performed the $\mathrm{Ag}(\mathrm{I})$-catalyzed deprotection of the TMS-protected alkyne moiety, followed by another CuAAC reaction of the unmasked terminal alkyne with the second azide, giving the desired bistriazole-linked pseudononapeptides $\mathbf{2 8}$ in good yield (88-93\%) .

In 2009, Perumal and co-workers developed a one-pot methodology [29] for the multicomponent cycloaddition of sodium azide, benzyl bromides and various $N$-propargylated bis(indolyl)arylmethanes 30 catalyzed by $\mathrm{CuI}$. It was proved that this multicomponent $\mathrm{CuAAC}$ reaction proceeded well in
PEG-400 among various solvents, mainly due to the hydrophilic and hydrophobic character of the PEG-400. As shown in Scheme 12, the CuAAC gave the desired bistriazoles $\mathbf{3 1}$ in good to excellent yield when electron-withdrawing groups were present in the benzyl bromides. Notably, the authors determined that all the compounds obtained showed potential biological activity.

Later, in 2011, Girard et al. demonstrated that the dialkynes with functional groups could react smoothly with various organic azides without the protection-deprotection step [30]. Initially, they first chose $N$-propargylpropiolamide $\mathbf{3 2}$ as the substrate and found the alkyne group with neighboring electronwithdrawing amide carbonyl was reacting exclusively with the organic azide under catalyst-free reaction conditions (with or without a solvent at room temperature) to give the mono-triazole intermediate $\mathbf{3 3}$ in good yield. Then the nonactivated terminal alkyne reacts with another azide, catalyzed by an Amberlyst A-21/CuI system in $\mathrm{CH}_{2} \mathrm{Cl}_{2}$ to form the second triazole ring with high yield (Scheme 13). In this work, the authors further extended this method to the propiolamide, which was derived from meta- and para-ethynylaniline, where both of the substrates worked well and the desired bistriazoles $\mathbf{3 4}$ could be obtained by a simple trituration and filtration procedure in good yield. 


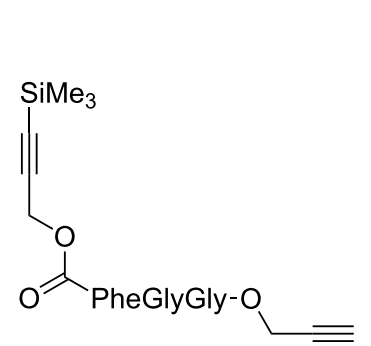

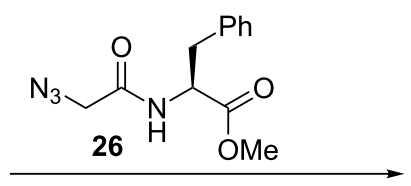

$\mathrm{CuSO}_{4}$ (0.1 equiv), sodium ascorbate ( 0.2 equiv), $t-\mathrm{BuOH} / \mathrm{H}_{2} \mathrm{O}, 35^{\circ} \mathrm{C}, 18 \mathrm{~h}$

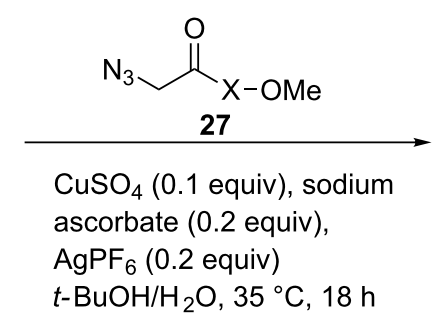

25<smiles>[R9]OC(=O)Cn1nncc1COC(=O)N[C@@H](Cc1ccccc1)C(=O)NCC(=O)NCC(=O)OCc1cn(CC(=O)N[C@@H](Cc2ccccc2)C(=O)OC)nn1</smiles>

X = Leu, Pro, Lys(Boc), 88-93\% yield

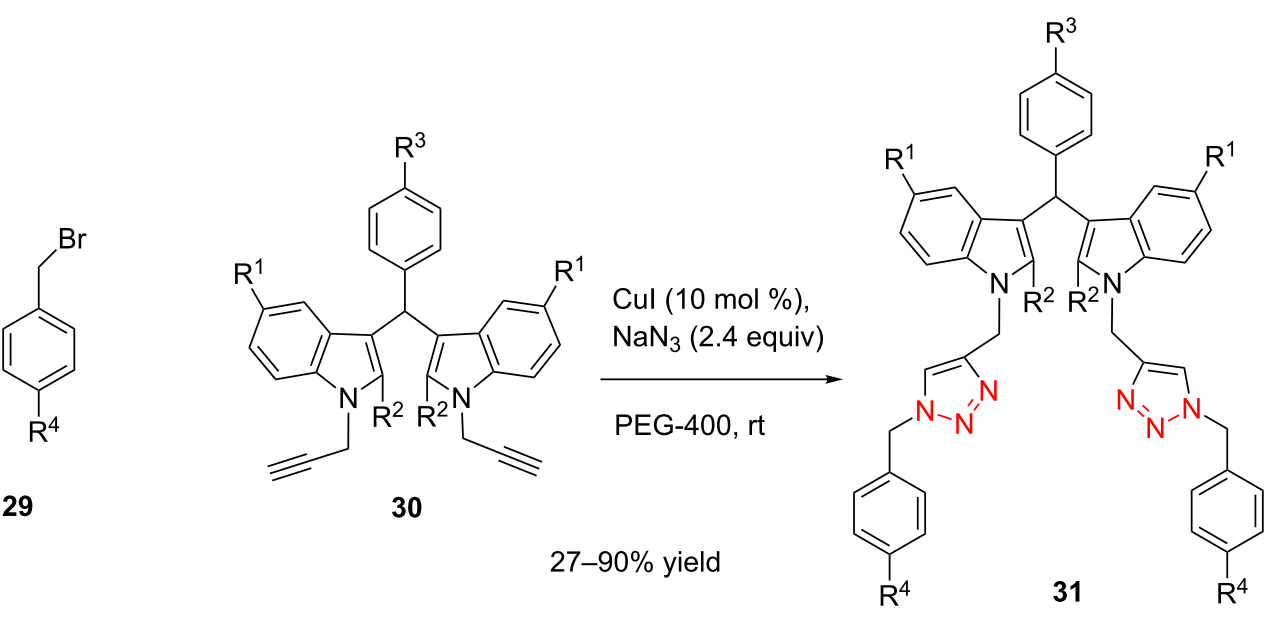

Scheme 12: The synthesis of bis(indolyl)methane-derivatized 1,2,3-bistriazoles.<smiles>C#CC(=O)Nc1cccc(C#C)c1</smiles>

32
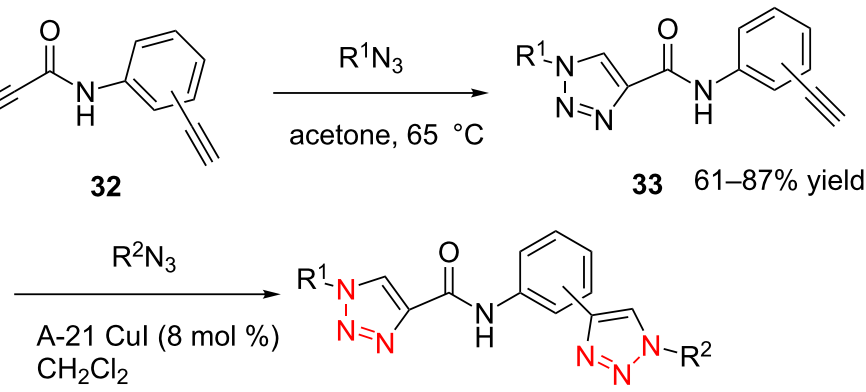

$3491-99 \%$ yield

Scheme 13: The sequential, chemoselective preparation of bistriazoles. 
The strain-promoted azide-alkyne cycloaddition (SPAAC) reaction could be well-performed without a $\mathrm{Cu}(\mathrm{I})$ catalyst. Such reactions are ideal for bioconjugation where no additional metal is required [31]. In 2012, Beal and co-workers incorporated the terminal alkyne and the activated cyclooctyne with two amide formation reactions [32], and then the SPAAC reaction was performed between the cyclooctyne $\mathbf{3 5}$ and the azides under mild conditions without the $\mathrm{Cu}(\mathrm{I})$. Notably, the $\mathrm{CuAAC}$ reaction between the terminal alkyne of $\mathbf{3 6}$ and various azides provided the desired bistriazoles 37 in good yield (Scheme 14).
Bistriazoles have potential application in the synthesis of surfactants after introducing the carbohydrate moiety. In 2012, Mohammed and co-workers selected the commercially available D-mannitol $\mathbf{3 8}$ as the starting material [33] in this reaction. After protection and introduction of the two alkyne groups to give dialkyne 39, the copper-catalyzed cycloaddition occurred smoothly with the different long chain alkyl azides under the optimized reaction conditions. This provided the desired bistriazoles $\mathbf{4 0}$ in good yield (Scheme 15). It should be noted that the deprotection of bistriazoles $\mathbf{4 0}$ gives the gemini surfactants $\mathbf{4 1}$<smiles>C#CCNC(=O)[C@H](CCCCNC(=O)C1(F)C#CCCCCC1)NC(=O)CSC(C)=O</smiles>

$\underset{\mathrm{DMSO}}{\stackrel{\mathrm{R}^{1} \mathrm{~N}_{3}(1.1 \text { equiv })}{\longrightarrow}}$

35<smiles>[Na][Mg][Mg]</smiles><smiles></smiles>

$\mathrm{R}^{2}$

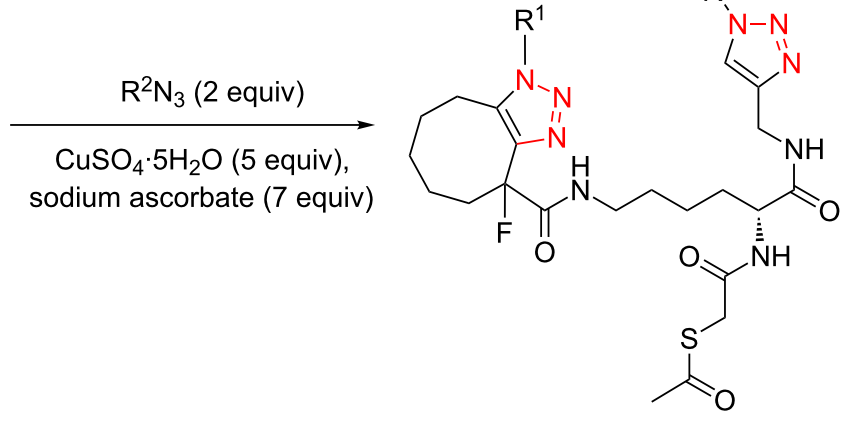

37 quantative<smiles>CC1(C)OC[C@@H](C(O)[C@H]2COC(C)(C)O2)O1</smiles>

38<smiles>[R]n1cc(COC(C(OCc2cn([R])nn2)[C@H]2COC(C)(C)O2)[C@H]2COC(C)(C)O2)nn1</smiles>

40

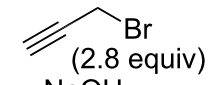

$\mathrm{NaOH}$

DMF, $-20^{\circ} \mathrm{C}$ to rt

$36 \mathrm{~h}$<smiles>C#CCOC([C@@H]1COC(C)(C)O1)[C@H]1COC(C)(C)O1</smiles>

39

Amberlite IR, $120 \mathrm{H}^{+}$

EtOH, reflux, $30 \mathrm{~h}$
$\mathrm{RN}_{3}$ (2.5 equiv),

$\mathrm{CuSO}_{4} \cdot 5 \mathrm{H}_{2} \mathrm{O}$ (0.01 equiv),

sodium ascorbate ( 0.2 equiv)

DMSO, $50^{\circ} \mathrm{C}, 36 \mathrm{~h}$<smiles>[R]n1cc(CO[C@@H]([C@@H](O)CO)[C@H](OCc2cn([R])nn2)[C@H](O)CO)nn1</smiles>

$41 \quad 80-99 \%$ yield 
(with two hydrophobic arms and two hydrophilic heads) in high yield.

In 2012, Kaushik and co-workers prepared a series of esterlinked dialkynes from the acid dichloride and propargyl alcohol in the presence of DMAP [34]. Here, the CuAAC reaction between the dialkynes $\mathbf{4 2}$ and the azides provided the desired bistriazoles 43 in good yield (70-92\%, Scheme 16). Interestingly, the antimicrobial activity studies revealed that compound 44 showed the highest activity against $B$. subtilis and E. coli due to the presence of a rigid pyridine nucleus. The authors further prepared various amide-linked bistriazoles by a three-component one-pot reaction of the amide-linked dialkynes, benzyl bromides and sodium azide catalyzed by $\mathrm{CuSO}_{4} \cdot 5 \mathrm{H}_{2} \mathrm{O}$ and sodium ascorbate in DMF $[35,36]$. All the obtained compounds were evaluated for in vitro cytotoxicity against a panel of five human cancer cell lines, where compounds $\mathbf{4 5}$ and $\mathbf{4 6}$ displayed the highest and broadest spectrum activity against all five cancer cell lines under study (Scheme 16).

The formation of triazole functional groups can work as a powerful auxochrome. In 2010, Bunz and co-workers used the TMS-protected diethynylbenzothiadiazoles $\mathbf{4 8}$ and $\mathbf{5 0}$ as the source of dialkynes. The CuAAC reaction was carried out with ethylene-glycol-functionalized azide $\mathbf{4 7}$ in the presence of $\mathrm{CuSO}_{4}$ and sodium ascorbate, providing the benzo-thiadiazolebased bistriazole (49 and 51, Scheme 17) [37]. With the aid of the hydrophilic character of the ethylene glycol group, both of<smiles>C#CCOC(=O)CCC(=O)OCC#C</smiles>

42

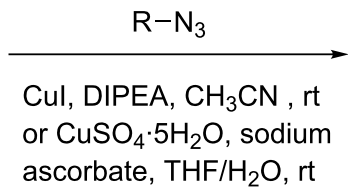

ascorbate, $\mathrm{THF} / \mathrm{H}_{2} \mathrm{O}$, rt

$n=1,2,3,4$

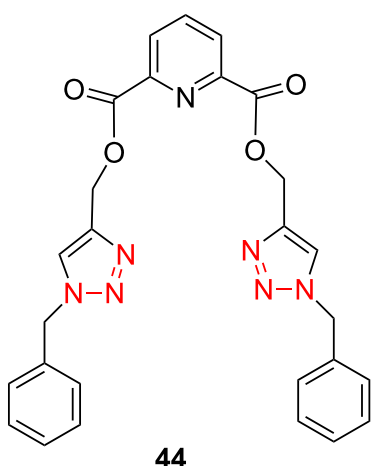

44

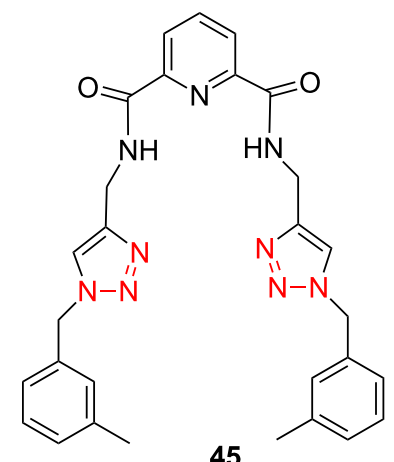

45<smiles>[R]n1cc(COC(=O)CCC(=O)OCc2cn([R])nn2)nn1</smiles>

$n=1,2,3,4 \quad 4370-92 \%$, yield

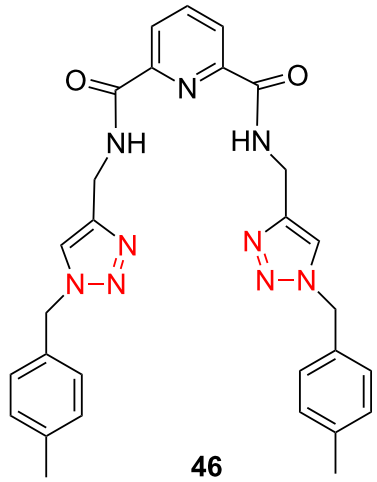

Scheme 16: The synthesis of ester-linked and amide-linked bistriazoles.<smiles>COCCOCCOCCn1cc(-c2ccc(-c3cn(CCOCCOC)nn3)c3nsnc23)nn1</smiles>

$\mathrm{R}=\mathrm{TMS}, \mathrm{H}, 55 \%$ yield

49

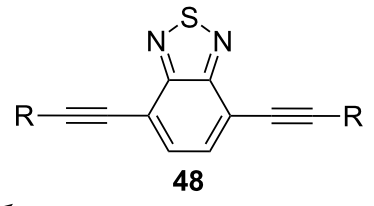

$\mathrm{KF}, \mathrm{CuSO}_{4}$ (2.5 equiv), sodium ascorbate (2.5 equiv)

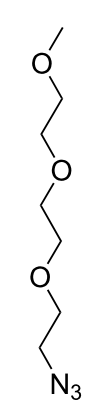

47

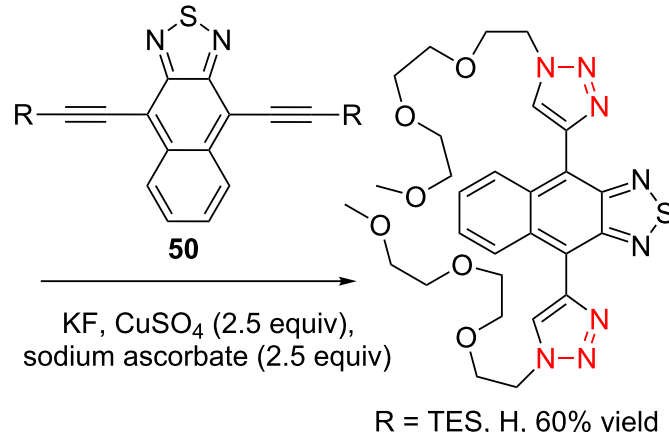

51

Scheme 17: The synthesis of acenothiadiazole-based bistriazoles. 
the bistriazoles can be endowed with water solubility, and can effectively bind $\mathrm{Cu}(\mathrm{II})$ and $\mathrm{Ni}(\mathrm{II})$ in water.

The thiacalix[4]arenes are sulfur-bridged analogs of calix[4]arenes, which have potential application in the molecular recognition of cationic, anionic or neutral molecules. In this regard, Yamato et al. incorporated two urea moieties possessing various aryl groups and two pyrene-appended triazole rings at the opposite side of the thiacalix[4]arene cavity [38]. The authors found that receptor $\mathbf{5 2}$ (Scheme 18) could selectively bind $\mathrm{Cl}^{-}$through hydrogen bonding interaction with the urea $\mathrm{NH}$ protons, and $\mathbf{5 2}$ can also bind with $\mathrm{Ag}^{+}$through complexation with the pyrene-appended bistriazole.

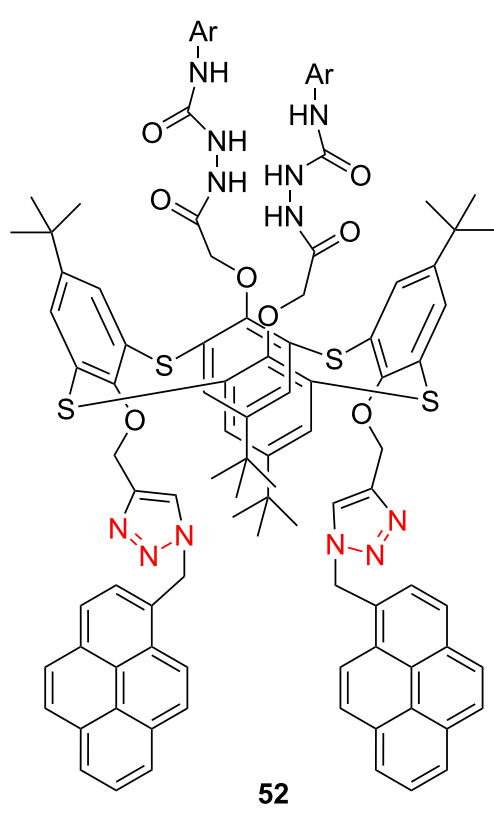

Scheme 18: The pyrene-appended thiacalix[4]arene-based bistriazole

In homogeneous catalysis, functional ligands often play a key role in transition metal catalysis. Accordingly, the bistriazole derivatives could provide promising alternatives to bipyridine ligands because of their powerful nitrogen-centered coordination. In this context, Hao and co-workers have reported bistria- zole-based N4 tetradentate ligands that were prepared by two $\mathrm{CuAAC}$ reactions in a one-pot procedure [39]. As shown in Scheme 19, these ligands exhibited good coordination properties to various metals, and the corresponding $\mathrm{Mn}$ (II) complexes showed good catalytic activity for the epoxidation of various aliphatic terminal olefins.

Very recently, Ulven and co-workers reported the synthesis of triazole-linked phenanthroline ligands. They were obtained by the following steps: (1) 1,10-phenanthroline-2,9-dicarbaldehyde (56) was treated with the Ohira-Bestmann reagent to provide the corresponding dialkyne 57; (2) Dialkyne 57 was reacted with different azides catalyzed by the $\mathrm{Cu}$ (II)-TBTA complex and sodium ascorbate in a bi-phasic system of $\mathrm{CH}_{2} \mathrm{Cl}_{2} /$ $\mathrm{H}_{2} \mathrm{O}$ as the solvent, giving the desired bistriazoles $\mathbf{5 9}$ in good yield; (3) Deprotection of the N-Boc group with TFA, and the obtained primary amines was transformed to the corresponding primary guanidine or diisopropylguanidine analogs (60 and 61, Scheme 20) [40], which could be used as potential G4 DNA ligands with high selectivity over duplexed DNA.

Similar to the above strategies or methods, a number of researchers have developed various dialkyne substrates with varied spacers. As shown in Table 1, the reaction conditions are summarized for comparison, including the catalysts, the solvents, and the application of the bistriazoles.

\section{Bistriazole synthesis with diazide spacers}

The spacer-linked bistriazoles could also be prepared by the $\mathrm{CuAAC}$ reaction of the in situ generated diazides with substitued alkynes. There are mainly two types of methods for the construction of bistriazoles from diazides: (1) Starting from the substrate-containing good-leaving groups, the diazides could be generated in situ by nucleophilic addition with $\mathrm{NaN}_{3}$, and then the double CuAAC reactions could give the desired bistriazoles. (2) Starting from a substrate containing one azide functionality and another suitable functional group, the $\mathrm{CuAAC}$ reaction was performed with a terminal alkyne to provide the monotriazole compound. Subsequently, the suitable functional group was transformed into the corresponding azide for the next $\mathrm{CuAAC}$ reaction to give the desired bistriazoles.

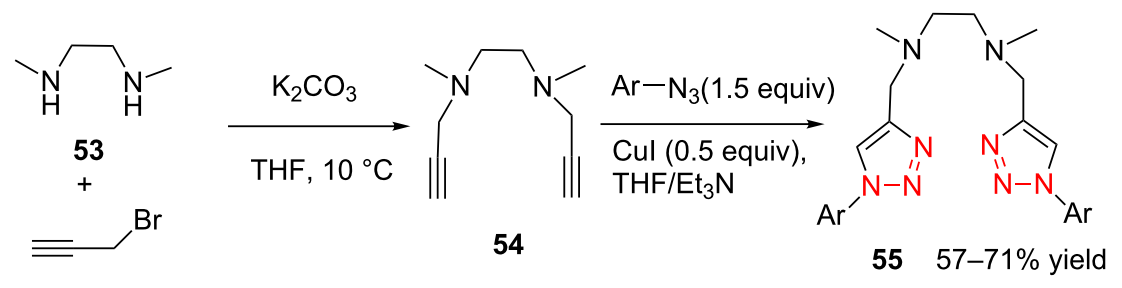




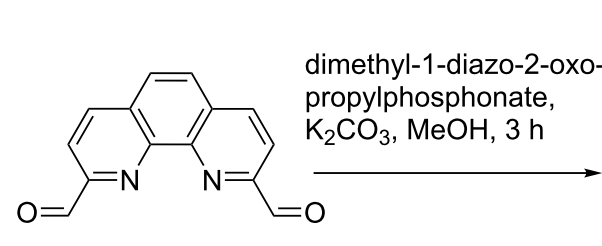

56

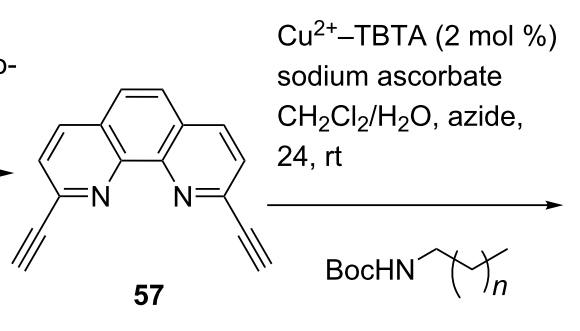

$57 \%$ yield

$$
n=1,2,3
$$

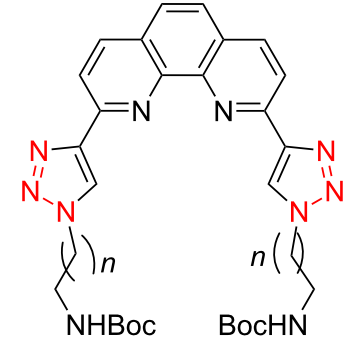

$5871-79 \%$ yield

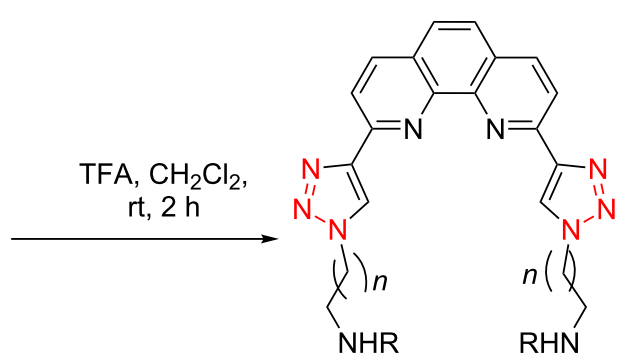

59 quantitative

1H-pyrazole-1-carboxamidine hydrochloride, $\mathrm{Et}_{3} \mathrm{~N}, \mathrm{EtOH}$

$120^{\circ} \mathrm{C}$ (microwave), $30 \mathrm{~min}$

$$
\mathrm{R}=\mathrm{C}(\mathrm{NH}) \mathrm{NH}_{2}
$$

$60,57-72 \%$ yield

$N, N^{\prime}$-diisopropylcarbodiimide, $\mathrm{Et}_{3} \mathrm{~N}, \mathrm{EtOH}$

$120^{\circ} \mathrm{C}$ (microwave), $30 \mathrm{~min}$

$$
\mathrm{R}=\mathrm{H}
$$

$\mathrm{R}=\mathrm{C}(\mathrm{N}-\mathrm{iPr}) \mathrm{NH}-\mathrm{iPr}$

$61,64-70 \%$ yield

\begin{tabular}{|c|c|c|c|c|}
\hline Cu source & Solvent & Spacer & Azide & Application \\
\hline $\begin{array}{c}\mathrm{CuSO}_{4} \cdot 5 \mathrm{H}_{2} \mathrm{O} \\
\text { sodium } \\
\text { ascorbate } \\
{[41]}\end{array}$ & $\mathrm{DMSO} / \mathrm{H}_{2} \mathrm{O}$ & & $\mathrm{BnN}_{3}$ & - \\
\hline $\begin{array}{c}\text { bioClick } \\
\text { conditions } \\
{[42]}\end{array}$ & - & & $\mathrm{R}=\mathrm{OH}$ or $\mathrm{Me}$ & Complexation \\
\hline $\begin{array}{c}\mathrm{CuSO}_{4} \cdot 5 \mathrm{H}_{2} \mathrm{O}, \\
\text { sodium } \\
\text { ascorbate } \\
{[43]}\end{array}$ & $\mathrm{CH}_{2} \mathrm{Cl}_{2} / \mathrm{H}_{2} \mathrm{O}$ & & $\begin{array}{c}6 \\
\text { azidosugars }\end{array}$ & - \\
\hline $\begin{array}{l}\text { A-21-Cul } \\
\quad[44]\end{array}$ & $\mathrm{CH}_{2} \mathrm{Cl}_{2}$ & $=$ & $\begin{array}{c}\mathrm{R}-\mathrm{N}_{3}, \mathrm{R}=\mathrm{Bn}, \mathrm{CH}_{2} \mathrm{CO}_{2} \mathrm{Et} \\
\quad\left(\mathrm{CH}_{2}\right)_{3} \mathrm{OAc},\left(\mathrm{CH}_{2}\right)_{3} \mathrm{OH}\end{array}$ & - \\
\hline
\end{tabular}

Scheme 20: The synthesis of phenanthroline-2,9-bistriazoles.

Table 1: Previous reports on the copper-catalyzed Huisgen cycloaddition to bistriazoles with spacers. 
Table 1: Previous reports on the copper-catalyzed Huisgen cycloaddition to bistriazoles with spacers. (continued)

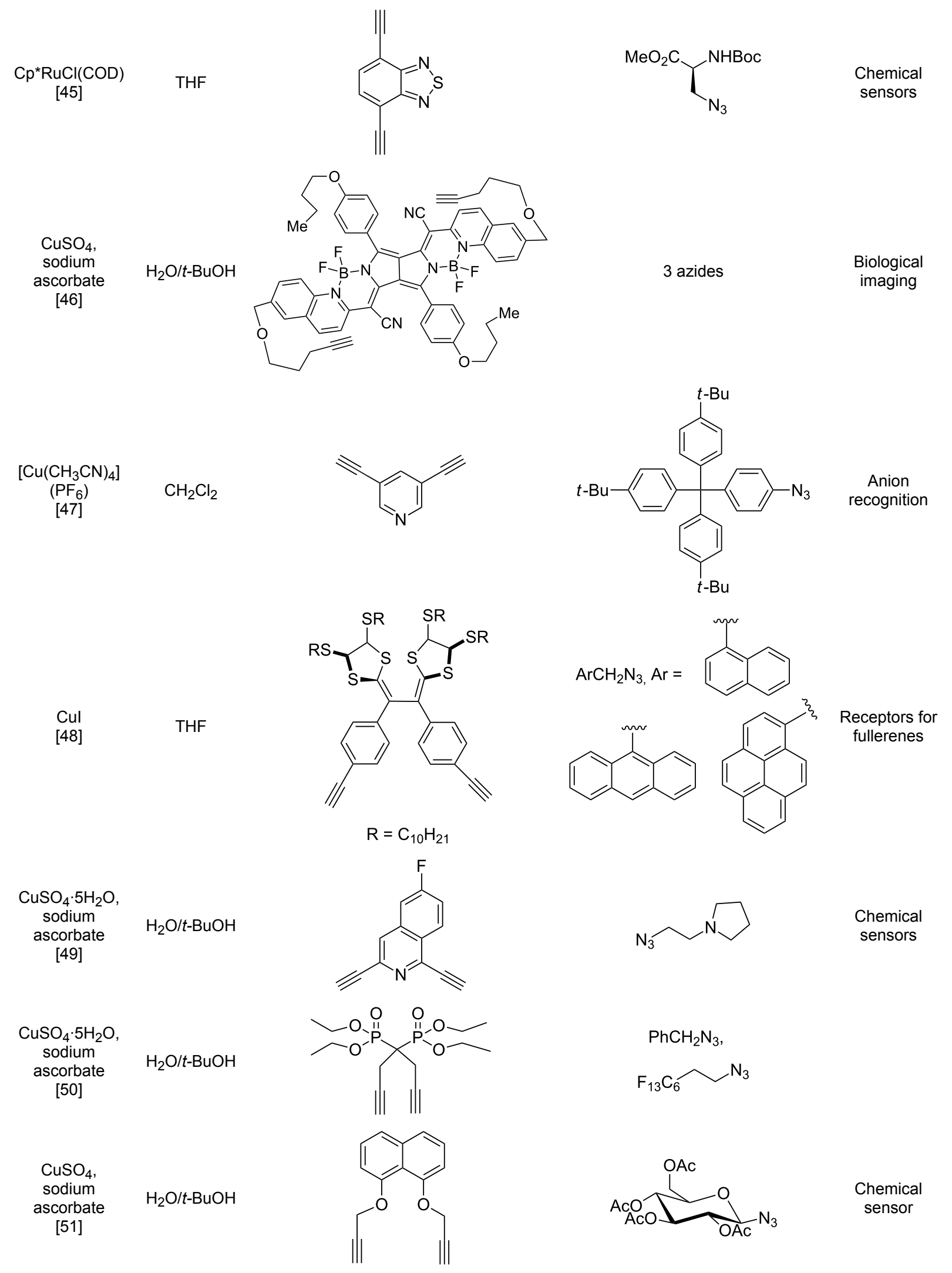


Table 1: Previous reports on the copper-catalyzed Huisgen cycloaddition to bistriazoles with spacers. (continued)

Cul<smiles>[R][R](=O)ON</smiles>

$\mathrm{CuSO}_{4} \cdot 5 \mathrm{H}_{2} \mathrm{O}$ sodium ascorbate

[53]

$\mathrm{CH}_{2} \mathrm{Cl}_{2} / \mathrm{H}_{2} \mathrm{O}$

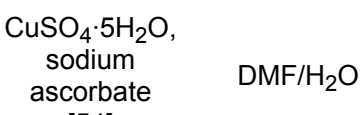

[54]

$$
\begin{gathered}
\mathrm{CuSO}_{4} \cdot 5 \mathrm{H}_{2} \mathrm{O} \\
\text { sodium } \\
\text { ascorbate }
\end{gathered}
$$

$\mathrm{DMF} / \mathrm{H}_{2} \mathrm{O}$

[55]

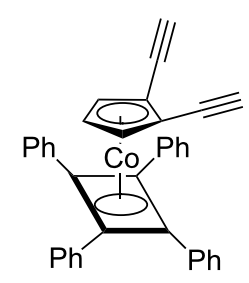<smiles>C#CCN(CC#C)c1nc2ccccc2s1</smiles><smiles>C#Cc1cccc(C#C)c1</smiles>

$\mathrm{EtOH} / \mathrm{H}_{2} \mathrm{O}$

$\mathrm{CuSO}_{4} \cdot 5 \mathrm{H}_{2} \mathrm{O}$, sodium ascorbate

[56]

$$
\underset{[57]}{\mathrm{CuSO}_{4} \cdot 5 \mathrm{H}_{2} \mathrm{O} / \mathrm{Cu}} \quad \mathrm{CH}_{3} \mathrm{CN}
$$

$\mathrm{CuSO}_{4}$ sodium ascorbate [58]

$\mathrm{H}_{2} \mathrm{O} / t-\mathrm{BuOH}$<smiles>[R]N1C(=O)[C@@H](N(CC#C)CC#C)[C@H]1/C=C/c1ccccc1</smiles><smiles>[X]C1=C(N[C@]([2H])(C(=O)OCC#C)C(C)(C)C(=O)OCCC#C)[C@H]([R6])OC1=O</smiles><smiles>C#CCOCCOCC#C</smiles>

$n=0,2,3,5,8$

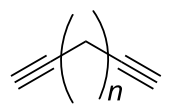

$n=4,12,18$

Cul

[59]

THF/ $\mathrm{H}_{2} \mathrm{O}$<smiles>[R]c1cccc(N)c1</smiles>

20 azides

$\mathrm{AcO}$<smiles>CCCCCN</smiles>

Biological activity

$\mathrm{PhCH}_{2} \mathrm{~N}_{3}$

R activity<smiles>COc1ccc(CN)cc1</smiles>
Complexation

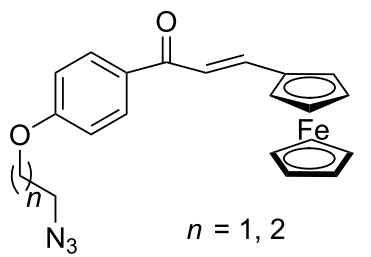

Antitubercular activity

Biological activity

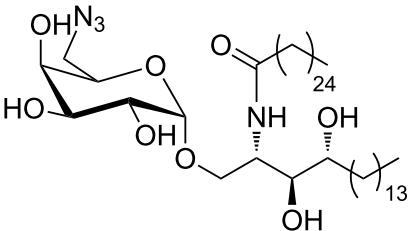

Chemical sensor 
Table 1: Previous reports on the copper-catalyzed Huisgen cycloaddition to bistriazoles with spacers. (continued)

$\mathrm{CuSO}_{4} \cdot 5 \mathrm{H}_{2} \mathrm{O}$
sodium
ascorbate

$[60]$

$\mathrm{CuSO}_{4}$ sodium ascorbate [61]

$\mathrm{Cul}$

$$
\text { [62] }
$$

$$
\mathrm{CH}_{3} \mathrm{CN}
$$

$\mathrm{Cu}\left(\mathrm{PPh}_{3}\right)_{3} \mathrm{Br}$ [63]

THF<smiles>C#CCOc1ccc(C=CC(=O)c2ccc(OCC#C)cc2)cc1</smiles><smiles>[R]c1ccc(C#C)cc1C#C</smiles>

$\mathrm{R}^{1} \mathrm{~N}_{3}$<smiles>[R]c1cccc(N)c1</smiles>

Antioxidant, antifungal activity

11 examples<smiles>C#Cc1ccc(C(=O)c2ccc(C#C)c(C#C)c2)cc1</smiles><smiles>[R]c1c(Cc2cc(C(C)(C)C)cc(Cc3cc(C(C)(C)C)cc(C(CCN)C(C)(C)C)c3[R])c2[R])cc(C(C)(C)C)cc1Cc1cc(C(C)(C)C)cc(C(C)C)c1[R]</smiles>

Chemical sensors<smiles></smiles>

$X=O, S, S e$

$$
\mathrm{R}=\mathrm{OMe}, n=1,2,4
$$

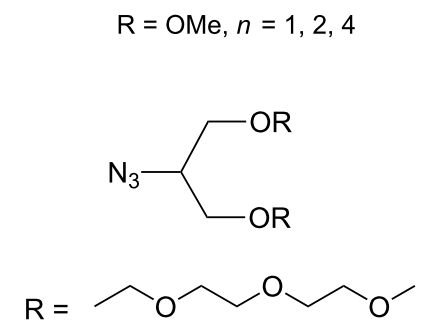

Chemical sensors
In 2007, Wang and co-workers demonstrated that the one-pot three-component reaction of ortho- and meta-bis(chloromethyl)benzene (62), sodium azide, and terminal alkynes, catalyzed by $\mathrm{CuX}$ in water could provide the corresponding 1,4disubstitued bistriazoles 63 in excellent yield [64] (Scheme 21). They found that the bistriazole could be formed during the Huisgen reaction, in which the reaction was efficiently promoted by the catalytic amount of the $\mathrm{Cu}(\mathrm{I})$ salts. For example, the three-component reaction could reach completion in the presence of only $0.2 \mathrm{~mol} \%$ of $\mathrm{Cu}(\mathrm{I})$.

In 2010, Shreeve et al. reported that the diazides $\mathbf{6 5}$ could be generated in situ by the nucleophilic substitution of $\mathrm{SF}_{5}$ and OTs groups wtih 3 equiv of $\mathrm{NaN}_{3}$, followed by the $\mathrm{CuAAC}$ reaction with aliphatic alkynes, providing the desired bistriazoles 66 in moderate yield (Scheme 22) [65]. However, when<smiles>ClCc1cccc(CCl)c1</smiles>

62

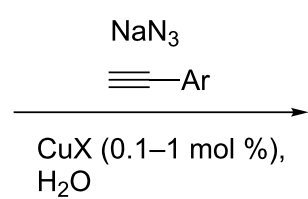

A<smiles>Brc1cn(Cc2cccc(Cn3cc(Br)nn3)c2)nn1</smiles>

$6387-93 \%$ yield 


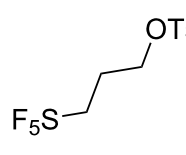

64 $\underset{\text { DMSO, } 80^{\circ} \mathrm{C}}{\stackrel{\mathrm{NaN}_{3} \text { (3 equiv) }}{\longrightarrow}}\left[\mathrm{N}_{3} \sim \mathrm{N}_{3}\right]$

65

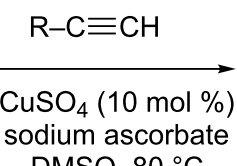

DMSO, $80^{\circ} \mathrm{C}$<smiles>[R]c1cn(CCCn2cc([R])nn2)nn1</smiles>

66

$\mathrm{R}=\mathrm{CF}_{3}$ or $n-\mathrm{Bu}$

$10 \%$ and $60 \%$ yield

Scheme 22: The one-pot synthesis of bistriazoles.

they choose the substrate $\mathrm{SF}_{5}$-ethylbromide, only trace amounts of the triazole-containing compound was obtained even after $18 \mathrm{~h}$ at $60{ }^{\circ} \mathrm{C}$ due to the poor leaving ability of the $\mathrm{Br}^{-}$ compared to the OTs group.

In 2011, Bundle et al. reported the double-click method for the formation of disymmetric bistriazoles [66]. The authors introduced the azide group (69) by the coupling of the protected amine functionality to the polymer substrate for the first CuAAC reaction (Scheme 23). Then, the treatment of the amine-containing mono-triazole intermediate $\mathbf{7 1}$ with the diazo transfer agent (imidazole-1-sulfonyl azide) was performed to convert the amine group into the corres- ponding azide group, which provided a polymeric substrate for the second $\mathrm{CuAAC}$ reaction to give the desired bistriazoles (Scheme 23).

In 2009, Zhu and co-workers found that copper(II) acetate $\left(\mathrm{Cu}(\mathrm{OAc})_{2}\right)$ could catalyze the Huisgen alkyne-azide cycloaddition reactions without the addition of the reducing agents and could be produced in high yield when the substrate contains the chelating azide group [67]. Then they synthesized the bifunctional compounds with chelating azide groups and nonchelating azide groups (compounds 75-78, Scheme 24) [68], by adding the $\mathrm{Cu}(\mathrm{OAc})_{2}$. This promoted the Huisgen cycloaddition of the chelating azide with the terminal alkyne, providing the mono-<smiles>CCC(C)CC(CC(CC(CC)C(N)=O)C(N)=O)C(N)=O</smiles>

67

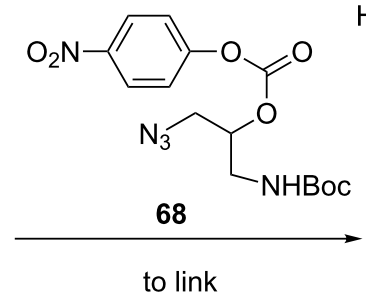

to link<smiles>CCC(CC(C)C(N)=O)CC(CC(CC(CC)C(N)=O)C(=O)NCCOCCOCCNC(=O)OC(CN)CN)C(N)=O</smiles>

69

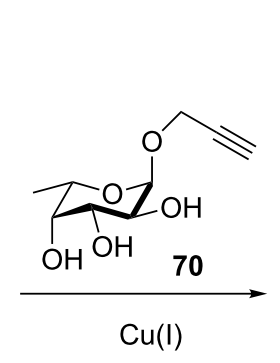

the first CuAAC<smiles>CCC(CC(C)C)CC(CC(CC)C(N)=O)C(=O)NCCOCCOCCNC(=O)OC(C)Cn1nnnn1</smiles><smiles>[R]CC#CC</smiles>

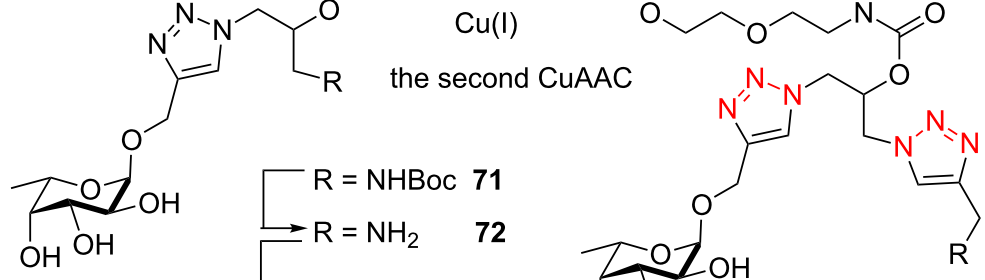

$\mathrm{R}=\mathrm{N}_{3}$ 73 $\mathrm{OH} \mathrm{OH}$ 
<smiles>NCCCCOCc1cccc(CN)n1</smiles>

75<smiles>NCCCCn1cc(CN)nn1</smiles>

76<smiles>N#CCc1ccc2nc(CN)ccc2c1</smiles>

77<smiles>NCc1ccc(CN)nc1</smiles>

78

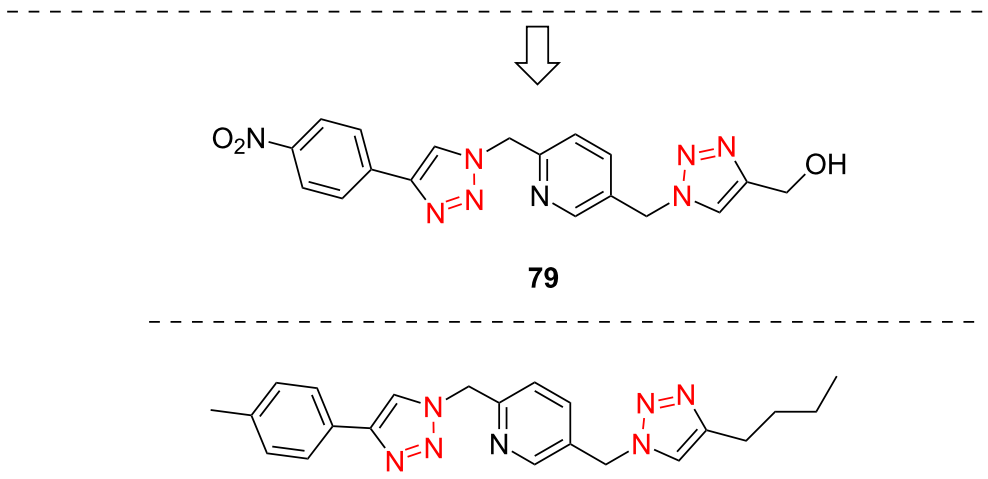

80

Scheme 24: The synthesis of bistriazoles via a sequential one-pot reaction.

triazole intermediates. Then, the introduction of the second alkyne, together with sodium ascorbate as the reducing agent, gave the desired bistriazoles in high yield. By mixing the two alkynes with different reactivities with the diazide, they developed a sequential one-pot method for the construction of the bistriazoles $(\mathbf{7 9}, \mathbf{8 0}$, etc.).
Notably, although there are many examples of the formation of spacer-linked bistriazoles from the diazide substrates, these bistriazole products were obtained with almost the same strategy as previously reported. These works are listed in Table 2 together with the reaction conditions and the applications of the corresponding bistriazoles.

Table 2: Previous reports on the copper-catalyzed Huisgen cycloaddition to bistriazoles with spacers

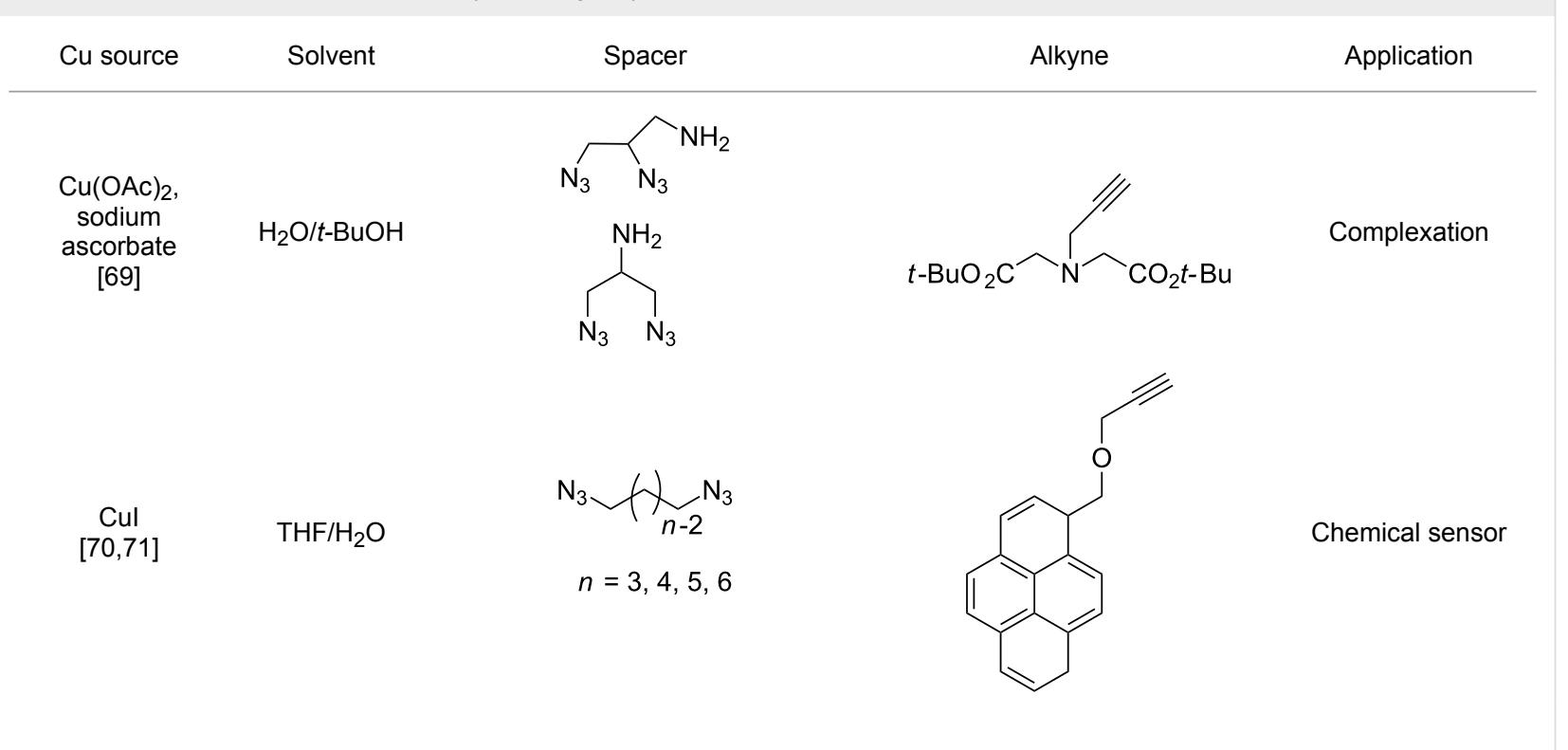


Table 2: Previous reports on the copper-catalyzed Huisgen cycloaddition to bistriazoles with spacers. (continued)

$\mathrm{CuSO}_{4} \cdot 5 \mathrm{H}_{2} \mathrm{O}$ sodium ascorbate

[72]

$\mathrm{CuSO}_{4} \cdot 5 \mathrm{H}_{2} \mathrm{O}$,
sodium
ascorbate
$[73]$

uSO $_{4} \cdot 5 \mathrm{H}_{2} \mathrm{O}$
sodium
ascorbate
[73]

uSO $_{4} \cdot 5 \mathrm{H}_{2} \mathrm{O}$
sodium
ascorbate
[73]

sodium
ascorbate
[73] DMF

$\mathrm{DMF} / \mathrm{H}_{2} \mathrm{O}$<smiles>NCCCCCN</smiles>

[74] $\mathrm{CHCl}_{3}$

$\mathrm{CuSO}_{4} \cdot 5 \mathrm{H}_{2} \mathrm{O}$, sodium ascorbate [75]

$\mathrm{CuSO}_{4} \cdot 5 \mathrm{H}_{2} \mathrm{O}$, sodium ascorbate

[76]

$\mathrm{H}_{2} \mathrm{O} / t-\mathrm{BuOH}$

$\mathrm{THF} / \mathrm{H}_{2} \mathrm{O}$<smiles>NCCCC[NH3+]</smiles><smiles>NCc1ccc(N)cc1</smiles><smiles>COc1cc(C(=O)N2CCC(N)C2)c([N+](=O)[O-])cc1Oc1ccc(CN)cc1</smiles>

$\mathrm{CuSO}_{4} \cdot 5 \mathrm{H}_{2} \mathrm{O}$, sodium ascorbate

$\mathrm{THF} / \mathrm{H}_{2} \mathrm{O}$

[77]

$\mathrm{CuSO}_{4} \cdot 5 \mathrm{H}_{2} \mathrm{O}$, sodium ascorbate

$\mathrm{DMF} / \mathrm{H}_{2} \mathrm{O}$<smiles>NCCN</smiles>

[78]

$\mathrm{Cu}(\mathrm{OAc})_{2} / \mathrm{Cu}$

[79]

DMSO

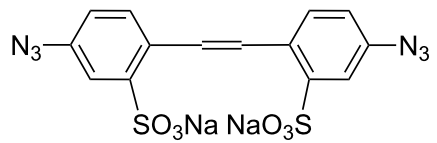<smiles>C#CCOc1ccc(COC(=O)c2cc([N+](=O)[O-])cc([N+](=O)[O-])c2)cc1</smiles>

Supermolecular chemistry

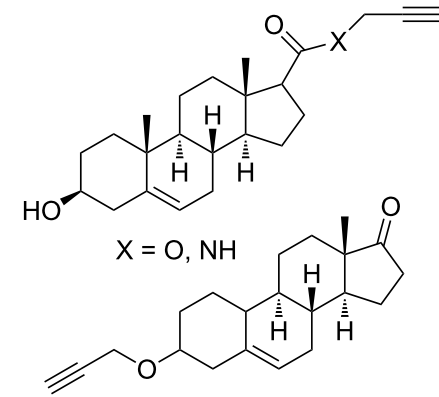

Cytotoxic activity

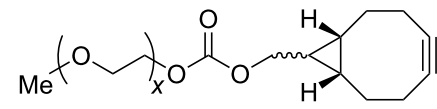

Polymer chemistry<smiles>C#CCC1(CC#C)c2ccccc2-c2ccccc21</smiles><smiles>C#CCOc1cc([N+](=O)[O-])c(C(=O)N2CCCC2)cc1OC</smiles>

DNA binding<smiles>C#Cc1cc2ccccc2c2ccccc12</smiles><smiles>C#Cc1ccccc1C(=O)C1CCCC1</smiles>

Receptor<smiles>C#CCn1c(-c2ccc(O)cc2)nc2ccccc2c1=O</smiles>

Molecular recognition<smiles>[R]C(N)C(=O)OCC#C</smiles><smiles>C[C@@H]1OC(=O)C(Br)=C1N</smiles>

$\mathrm{R}=\mathrm{CH}_{3}$ or $\mathrm{CH}_{2} \mathrm{CH}\left(\mathrm{CH}_{3}\right)_{2}$ 
Table 2: Previous reports on the copper-catalyzed Huisgen cycloaddition to bistriazoles with spacers. (continued)

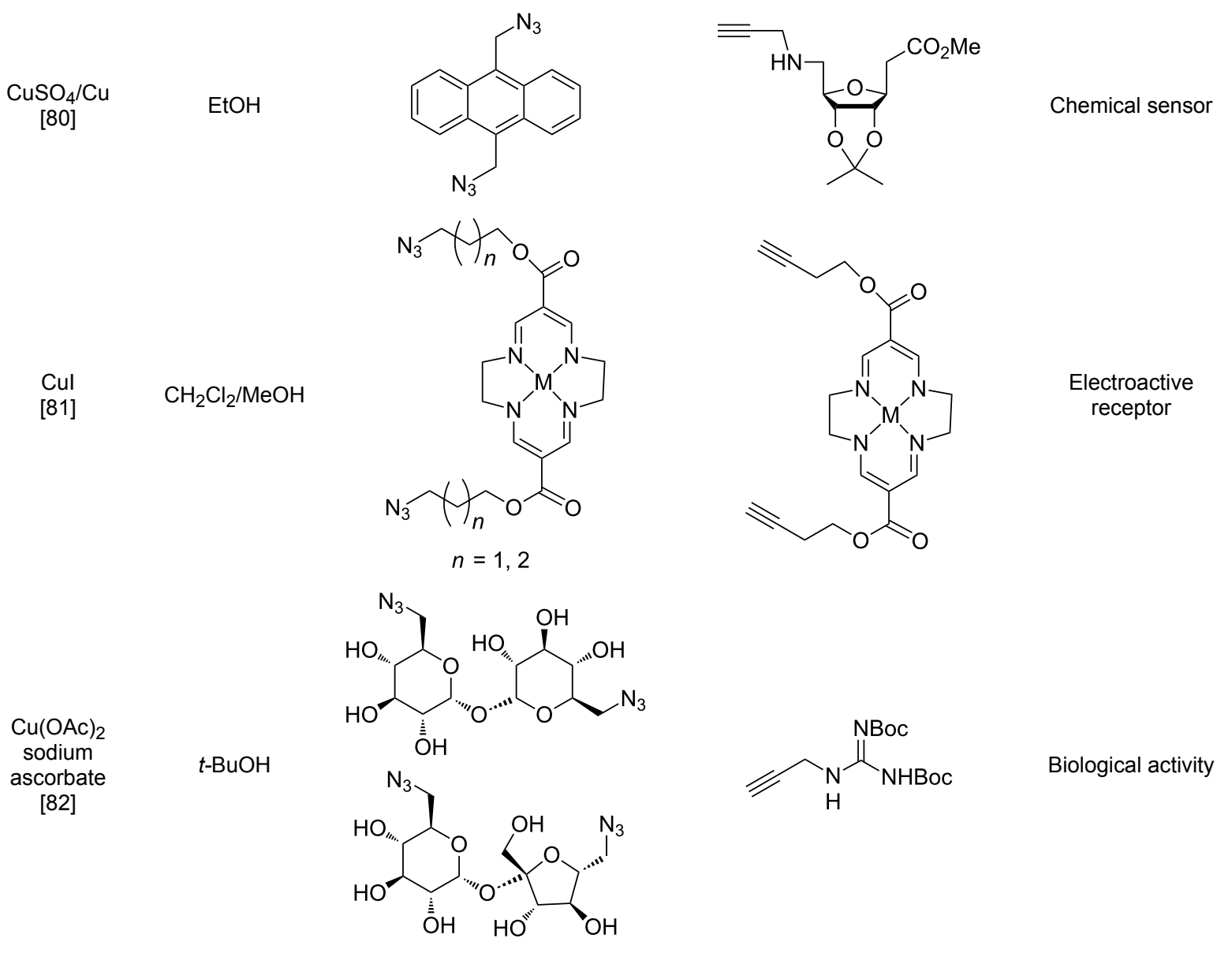

\section{Conclusion}

During the past 15 years, the $\mathrm{CuAAC}$ reaction has become a powerful tool for the synthesis of a large number of 1,4-disubstituted 1,2,3-triazoles and has led to applications in almost every field of chemistry and biochemistry. In this review, we summarized the recent progress of the $\mathrm{CuAAC}$ reaction, together with various popular related reactions, which have unexpected potential to yield the 4,4'-, 5,5'-bitriazoles or spacerlinked bistriazoles. Nevertheless, as compared to the classic spacer-linked bistriazoles, the chemistry of 4,4'-, and 5,5'-bitriazoles (both their preparation and application) are still in their infancy. Although we restricted this review to describe only those having a bistriazole backbone, one can easily obtain a glimpse into the huge potential of bistriazoles in the broad sense when added to all other substitution possibilities. This topic, although already widely studied in the past years, is still continuously evolving and regularly brings new possibilities in click chemistry. We feel that this compilation will be beneficial to design practical approaches and better routes to improve the existing routes for the synthesis of synthetically useful bi- and bistriazoles, and we expect that the pace of discovery of the application of bi- and bistriazoles in many fields will continue to increase for some time.

\section{Acknowledgements}

This project support by the National Natural Science Founder of China (No. 21173064, 51303043, and 21472031) and Zhejiang Provincial Natural Science Foundation of China (LR14B030001) is appreciated. Z. J. Zheng also thanks the financial support of the public project of Zhejiang Province (2014C31131).

\section{References}

1. Huisgen, R. Pure Appl. Chem. 1989, 61, 613-628. doi:10.1351/pac198961040613

2. Huisgen, R.; Szeimies, G.; Möbius, L. Chem. Ber. 1967, 100, 2494-2507. doi:10.1002/cber.19671000806

3. Bastide, J.; Hamelin, J.; Texier, F.; Ven, V. Q. Bull. Soc. Chim. Fr. 1973, 2555-2579.

4. Bastide, J.; Hamelin, J.; Texier, F.; Ven, V. Q. Bull. Soc. Chim. Fr. 1973, 2871-2887. 
5. Alvarez, R.; Velazquez, S.; San-Felix, A.; Aquaro, S.; De Clercq, E.; Perno, C.-F.; Karlsson, A.; Balzarini, J.; Camarasa, M. J. J. Med. Chem. 1994, 37, 4185-4194. doi:10.1021/jm00050a015

6. Genin, M. J.; Allwine, D. A.; Anderson, D. J.; Barbachyn, M. R.; Emmert, D. E.; Garmon, S. A.; Graber, D. R.; Grega, K. C.; Hester, J. B.; Hutchinson, D. K.; Morris, J.; Reischer, R. J.; Ford, C. W.; Zurenko, G. E.; Hamel, J. C.; Schaadt, R. D.; Stapert, D.; Yagi, B. H. J. Med. Chem. 2000, 43, 953-970. doi:10.1021/jm990373e

7. Brockunier, L. L.; Parmee, E. R.; Ok, H. O.; Candelore, M. R.; Cascieri, M. A.; Colwell, L. F., Jr.; Deng, L.; Feeney, W. P.; Forrest, M. J.; Hom, G. J.; MacIntyre, D. E.; Tota, L.; Wyvratt, M. J.; Fisher, M. H.; Weber, A. E. Bioorg. Med. Chem. Lett. 2000, 10, 2111-2114. doi:10.1016/S0960-894X(00)00422-4

8. Fan, W.-Q.; Katritzky, A. R. In Comprehensive heterocyclic chemistry II; Katritzky, A. R.; Rees, C. W.; Scriven, E. F. V., Eds.; Elsevier Science: Oxford, 1996; Vol. 4, pp 1-126.

9. Tornøe, C. W.; Christensen, C.; Meldal, M. J. Org. Chem. 2002, 67, 3057-3064. doi:10.1021/jo011148j

10. Rostovtsev, V. V.; Green, L. G.; Fokin, V. V.; Sharpless, K. B. Angew. Chem., Int. Ed. 2002, 41, 2596-2599. doi:10.1002/1521-3773(20020715)41:14<2596::AID-ANIE2596>3.0.CO ;2-4

11. Moses, J. E.; Moorhouse, A. D. Chem. Soc. Rev. 2007, 36, 1249-1262. doi:10.1039/b613014n

12. Finn, M. G.; Fokin, V. V. Chem. Soc. Rev. 2010, 39, 1231-1232. doi:10.1039/c003740k

13. Ganesh, V.; Sudhir, V. S.; Kundu, T.; Chandrasekaran, S. Chem. - Asian J. 2011, 6, 2670-2694. doi:10.1002/asia.201100408

14. Thirumurugan, P.; Matosiuk, D.; Jozwiak, K. Chem. Rev. 2013, 113, 4905-4979. doi:10.1021/cr200409f

15. Tang, W.; Becker, M. L. Chem. Soc. Rev. 2014, 43, 7013-7039. doi:10.1039/C4CS00139G

16. Meldal, M.; Tornøe, C. W. Chem. Rev. 2008, 108, 2952-3015. doi:10.1021/cr0783479

17. Monkowius, U.; Ritter, S.; König, B.; Zabel, M.; Yersin, H. Eur. J. Inorg. Chem. 2007, 4597-4606. doi:10.1002/ejic.200700479

18. Fiandanese, V.; Bottalico, D.; Marchese, G.; Punzi, A.; Capuzzolo, F. Tetrahedron 2009, 65, 10573-10580. doi:10.1016/j.tet.2009.10.078

19. Doak, B. C.; Scanlon, M. J.; Simpson, J. S. Org. Lett. 2011, 13, 537-539. doi:10.1021/ol102852z

20. Aizpurua, J. M.; Azcune, I.; Fratila, R. M.; Balentova, E.; Sagartzazu-Aizpurua, M.; Miranda, J. I. Org. Lett. 2010, 12 , 1584-1587. doi:10.1021/ol1003127

21. Angell, Y.; Burgess, K. Angew. Chem., Int. Ed. 2007, 46, 3649-3651. doi:10.1002/anie.200700399

22. Oladeinde, O. A.; Hong, S. Y.; Holland, R. J.; Maciag, A. E.; Keefer, L. K.; Saavedra, J. E.; Nandurdikar, R. S. Org. Lett. 2010, 12 4256-4259. doi:10.1021/ol101645k

23. del Hoyo, A. M.; Latorre, A.; Diaz, R.; Urbano, A.; Carreño, M. C. Adv. Synth. Catal. 2015, 357, 1154-1160. doi:10.1002/adsc.201400998

24. González, J.; Pérez, V. M.; Jiménez, D. O.; Lopez-Valdez, G.; Corana, D.; Cuevas-Yañez, E. Tetrahedron Lett. 2011, 52, 3514-3517. doi:10.1016/j.tetlet.2011.05.002

25. Kwon, M.; Jang, Y.; Yoon, S.; Yang, D.; Jeon, H. B. Tetrahedron Lett. 2012, 53, 1606-1609. doi:10.1016/j.tetlet.2012.01.069

26. Zheng, Z.-J.; Ye, F.; Zheng, L.-S.; Yang, K.-F.; Lai, G.-Q.; Xu, L.-W. Chem. - Eur. J. 2012, 18, 14094-14099. doi:10.1002/chem.201202472

27. Wang, C.-Y.; Zou, J.-F.; Zheng, Z.-J.; Huang, W.-S.; Li, L.; Xu, L.-W. RSC Adv. 2014, 4, 54256-54262. doi:10.1039/c4ra09589h
28. Aucagne, V.; Leigh, D. A. Org. Lett. 2006, 8, 4505-4507. doi:10.1021/ol061657d

29. Damodiran, M.; Muralidharan, D.; Perumal, P. T. Bioorg. Med. Chem. Lett. 2009, 19, 3611-3614. doi:10.1016/j.bmcl.2009.04.131

30. Elamari, H.; Meganem, F.; Herscovici, J.; Girard, C. Tetrahedron Lett. 2011, 52, 658-660. doi:10.1016/j.tetlet.2010.11.141

31. Kele, P.; Mezö, G.; Achatz, D.; Wolfbeis, O. S. Angew. Chem., Int. Ed. 2009, 48, 344-347. doi:10.1002/anie.200804514

32. Beal, D. M.; Albrow, V. E.; Burslem, G.; Hitchen, L.; Fernandes, C.; Lapthorn, C.; Roberts, L. R.; Selby, M. D.; Jones, L. H. Org. Biomol. Chem. 2012, 10, 548-554. doi:10.1039/c1ob06398g

33. Mohammed, A. I.; Abboud, Z. H.; Alghanimi, A. H. O. Tetrahedron Lett. 2012, 53, 5081-5083. doi:10.1016/j.tetlet.2012.07.014

34. Lal, K.; Kumar, A.; Pavan, M. S.; Kaushik, C. P. Bioorg. Med. Chem. Lett. 2012, 22, 4353-4357. doi:10.1016/j.bmcl.2012.05.008

35. Lal, K.; Kaushik, C. P.; Kumar, K.; Kumar, A.; Qazi, A. K.; Hamid, A.; Jaglan, S. Med. Chem. Res. 2014, 23, 4761-4770. doi:10.1007/s00044-014-1038-5

36. Lal, K.; Kaushik, C. P.; Kumar, A. Med. Chem. Res. 2015, 24, 3258-3271. doi:10.1007/s00044-015-1378-9

37. Brombosz, S. M.; Appleton, A. L.; Zappas, A. J., II; Bunz, U. H. F. Chem. Commun. 2010, 46, 1419-1421. doi:10.1039/b920484a

38. Tomiyasu, H.; Shigyo, N.; Ni, X.-L.; Zeng, X.; Redshaw, C.; Yamato, T. Tetrahedron 2014, 70, 7893-7899. doi:10.1016/j.tet.2014.08.068

39. Hao, E.; Wang, Z.; Jiao, L.; Wang, S. Dalton Trans. 2010, 39, 2660-2666. doi:10.1039/b922043g

40. Nielsen, M. C.; Larsen, A. F.; Abdikadir, F. H.; Ulven, T. Eur. J. Med. Chem. 2014, 72, 119-126. doi:10.1016/j.ejmech.2013.11.027

41. Zhang, X.; Li, H.; You, L.; Tang, Y.; Hsung, R. P. Adv. Synth. Catal. 2006, 348, 2437-2442. doi:10.1002/adsc.200600404

42. Li, Y.; Huffman, J. C.; Flood, A. H. Chem. Commun. 2007, 2692-2694. doi:10.1039/b703301j

43. Pereira, G. R.; Santos, L. J.; Luduvico, I.; Alves, R. B.; Pereira de Freitas, R. Tetrahedron Lett. 2010, 51, 1022-1025. doi:10.1016/j.tetlet.2009.12.050

44. Elamari, H.; Jlalia, I.; Louet, C.; Herscovici, J.; Meganem, F.; Girard, C. Tetrahedron: Asymmetry 2010, 21, 1179-1183. doi:10.1016/j.tetasy.2010.06.013

45. Ruan, Y.-B.; Yu, Y.; Li, C.; Bogliotti, N.; Tang, J.; Xie, J. Tetrahedron 2013, 69, 4603-4608. doi:10.1016/j.tet.2013.04.024

46. Zhou, M.; Zhang, X.; Bai, M.; Shen, D.; Xu, B.; Kao, J.; Ge, X.; Achilefu, S. RSC Adv. 2013, 3, 6756-6758. doi:10.1039/c3ra40441b

47. White, N. G.; Beer, P. D. Org. Biomol. Chem. 2013, 11, 1326-1333. doi:10.1039/c2ob27229f

48. Mulla, K.; Shaik, H.; Thompson, D. W.; Zhao, Y. Org. Lett. 2013, 15, 4532-4535. doi:10.1021/ol402093a

49. Midya, G. C.; Paladhi, S.; Bhowmik, S.; Saha, S.; Dash, J. Org. Biomol. Chem. 2013, 11, 3057-3063. doi:10.1039/c3ob40075a

50. Skarpos, H.; Osipov, S. N.; Vorob'eva, D. V.; Odinets, I. L.; Lork, E.; Röschenthaler, G.-V. Org. Biomol. Chem. 2007, 5, 2361-2367. doi:10.1039/b705510b

51. Hemamalini, A.; Mohan Das, T. New J. Chem. 2013, 37, 2419-2425. doi:10.1039/c3nj00072a

52. Krim, J.; Taourirte, M.; Engels, J. W. Molecules 2012, 17, 179-190 doi:10.3390/molecules17010179

53. Singh, N.; Metla, B. P. R.; Elias, A. J. J. Organomet. Chem. 2012, 717, 99-107. doi:10.1016/j.jorganchem.2012.07.023 
54. Singh, M. K.; Tilak, R.; Nath, G.; Awasthi, S. K.; Agarwal, A. Eur. J. Med. Chem. 2013, 63, 635-644. doi:10.1016/j.ejmech.2013.02.027

55. Scott, S. Ø.; Gavey, E. L.; Lind, S. J.; Gordon, K. C.; Crowley, J. D. Dalton Trans. 2011, 40, 12117-12124. doi:10.1039/c1dt10551e

56. Kumar, K.; Carrère-Kremer, S.; Kremer, L.; Guérardel, Y.; Biot, C.; Kumar, V. Dalton Trans. 2013, 42, 1492-1500. doi:10.1039/c2dt32148c

57. Huo, J.-P.; Lü, M.; Wang, Z.; Li, Y. Chin. J. Chem. 2012, 30 , 2411-2422. doi:10.1002/cjoc.201200638

58. Jervis, P. J.; Moulis, M.; Jukes, J.-P.; Ghadbane, H.; Cox, L. R.; Cerundolo, V.; Besra, G. S. Carbohydr. Res. 2012, 356, 152-162. doi:10.1016/j.carres.2012.02.034

59. Xu, H.-R.; Li, K.; Liu, Q.; Wu, T.-M.; Wang, M.-Q.; Hou, J.-T.; Huang, Z.; Xie, Y.-M.; Yu, X.-Q. Analyst 2013, 138, 2329-2334. doi:10.1039/c3an36789d

60. Anthony, P.; Bashir, N.; Parveen, R. Asian J. Pharm. Sci. 2014, 4, 9-13. doi:10.15272/ajbps.v4i33.501

61. Asmus, S.; Beckendorf, S.; Zurro, M.; Mück-Lichtenfeld, C.; Fröhlich, R.; Mancheño, O. G. Chem. - Asian J. 2014, 9, 2178-2186. doi:10.1002/asia.201402237

62. Fischer, C.; Weber, E. J. Inclusion Phenom. Macrocyclic Chem. 2014, 79, 151-160. doi:10.1007/s10847-013-0338-6

63. Bryant, J. J.; Lindner, B. D.; Bunz, U. H. F. J. Org. Chem. 2013, 78, 1038-1044. doi:10.1021/jo3024889

64. Wang, Z.-X.; Zhao, Z.-G. J. Heterocycl. Chem. 2007, 44, 89-92. doi:10.1002/jhet.5570440115

65. Huang, Y.; Gard, G. L.; Shreeve, J. M. Tetrahedron Lett. 2010, 51, 6951-6954. doi:10.1016/j.tetlet.2010.10.149

66. Guiard, J.; Fiege, B.; Kitov, P. I.; Peters, T.; Bundle, D. R. Chem. - Eur. J. 2011, 17, 7438-7441. doi:10.1002/chem.201003414

67. Brotherton, W. S.; Michaels, H. A.; Simmons, J. T.; Clark, R. J.; Dalal, N. S.; Zhu, L. Org. Lett. 2009, 11, 4954-4957. doi:10.1021/ol9021113

68. Yuan, Z.; Kuang, G.-C.; Clark, R. J.; Zhu, L. Org. Lett. 2012, 14, 2590-2593. doi:10.1021/ol300899n

69. Camp, C.; Dorbes, S.; Picard, C.; Benoist, E. Tetrahedron Lett. 2008, 49, 1979-1983. doi:10.1016/j.tetlet.2008.01.086

70. Hung, H.-C.; Cheng, C.-W.; Ho, I.-T.; Chung, W.-S. Tetrahedron Lett. 2009, 50, 302-305. doi:10.1016/j.tetlet.2008.10.147

71. Hung, H.-C.; Cheng, C.-W.; Wang, Y.-Y.; Chen, Y.-J.; Chung, W.-S. Eur. J. Org. Chem. 2009, 6360-6366. doi:10.1002/ejoc.200900987

72. Wei, P.; Yan, X.; Li, J.; Ma, Y.; Yao, Y.; Huang, F. Tetrahedron 2012, 68, 9179-9185. doi:10.1016/j.tet.2012.09.018

73. Jurášek, M.; Džubák, P.; Sedlák, D.; Dvořáková, H.; Hajdúch, M.; Bartůněk, P.; Drašar, P. Steroids 2013, 78, 356-361. doi:10.1016/j.steroids.2012.11.016

74. Isaacman, M. J.; Corigliano, E. M.; Theogarajan, L. S. Biomacromolecules 2013, 14, 2996-3000. doi:10.1021/bm400940h

75. Rajesh, R.; Periyasami, G.; Raghunathan, R. Tetrahedron Lett. 2010, 51, 1896-1898. doi:10.1016/j.tetlet.2010.02.020

76. Kamal, A.; Shankaraiah, N.; Reddy, C. R.; Prabhakar, S.; Markandeya, N.; Srivastava, H. K.; Sastry, G. N. Tetrahedron 2010, 66, 5498-5506. doi:10.1016/j.tet.2010.05.003

77. Romero, T.; Orenes, R. A.; Tárraga, A.; Molina, P. Organometallics 2013, 32, 5740-5753. doi:10.1021/om4002457

78. Karuturi, R.; Al-Horani, R. A.; Mehta, S. C.; Gailani, D.; Desai, U. R. J. Med. Chem. 2013, 56, 2415-2428. doi:10.1021/jm301757v

79. Huo, J.-P.; Luo, J.-C.; Wu, W.; Xiong, J.-F.; Mo, G.-Z.; Wang, Z.-Y. Ind. Eng. Chem. Res. 2013, 52, 11850-11857. doi:10.1021/ie401149p
80. Huang, H.-J.; Fang, H.-Y.; Chir, J.-L.; Wu, A.-T. Luminescence 2011, 26, 518-522. doi:10.1002/bio.1263

81. Mames, I.; Wawrzyniak, U. E.; Woźny, M.; Bilewicz, R.; Korybut-Daszkiewicz, B. Dalton Trans. 2013, 42, 2382-2391. doi:10.1039/c2dt32386a

82. Westermann, B.; Dörner, S.; Brauch, S.; Schaks, A.; Heinke, R.; Stark, S.; van Delft, F. L.; van Berkel, S. S. Carbohydr. Res. 2013, 371, 61-67. doi:10.1016/j.carres.2013.02.003

\section{License and Terms}

This is an Open Access article under the terms of the Creative Commons Attribution License

(http://creativecommons.org/licenses/by/2.0), which permits unrestricted use, distribution, and reproduction in any medium, provided the original work is properly cited.

The license is subject to the Beilstein Journal of Organic Chemistry terms and conditions: (http://www.beilstein-journals.org/bjoc)

The definitive version of this article is the electronic one which can be found at: doi:10.3762/bjoc. 11.276 